Original Research Paper

\title{
About Robotics, Mechatronics and Automation that Help us Conquer the Cosmic Space
}

\author{
Relly Victoria Virgil Petrescu \\ ARoTMM-IFToMM, Bucharest Polytechnic University, Bucharest (CE), Romania
}

\section{Article history}

Received: 14-04-2019

Revised: 20-04-2019

Accepted: 04-05-2019

Corresponding Author: Relly Victoria Virgil Petrescu ARoTMM-IFToMM, Bucharest Polytechnic University, Bucharest (CE), Romania Email: rvvpetrescu@gmail.com

\begin{abstract}
Here we have to mention that all these SF writings and many others that have existed over time, especially in the 20th century, have influenced alongside obvious screenings, young people and not just them, to think more about our role, robots, into a better world. The robot's key role is to help the man make his work easier, safer, more enjoyable, just like a computerized machine that helps us work faster and better, the robot has an obvious role in making work easier, to work in our place when we are tired, when work is exhausting and repetitive, when the environment is toxic, hostile, dangerous and in many other situations. However, it is time to say that the role of the robot in the future is altogether another, namely, to help us conquer the cosmic space to expand ourselves as a race in the whole universe in which we are now. In fact, this is the robot's humanitarian role and in the future, it can be developed and prepared just for that purpose. Exploratory robots are robots that operate in hard-to-reach and dangerous locations, telegraph or partially autonomous. They can work for example in a region in military conflict, on the Moon or on Mars. A geared navigation on the ground in the last two cases is impossible due to distance. Communication signals arrive at their destination in a matter of hours and their reception lasts as long. In such situations, robots have to be programmed with several types of behavior, from which they choose the most appropriate and execute it. This type of robot equipped with sensors was also used to research pyramid wells. Several cryobots (cryo robots) have already been tested by NASA in Antarctica. This type of robot can reach up to 3,600 m through the ice. Cryobots can thus be used in polar head research on Mars and Europe in the hope of alien living. NASA has always said that understanding how to live and work in space for long periods of time has been a key goal of the International Space Station. But, from the White House, it may seem expensive this race around the Earth, considering that the mission costs about $\$$ 8 million a day. Space makes us anxious. We are anxious that things go smoothly as if space flight should be infallible like a flight to London. And we are looking forward to a return on investment. We fly in space because of human ambition, because nothing gives us more resistance than trying to do what we have not done before. And we're flying in space because space is the eighth continent. We may eventually need asteroid or lunar resources, depending on how we manage the resources we have here on Earth. Eventually, we should become a species that will conquer other planets, whether we are no longer inside or that we actually destroy it or it will be destroyed.
\end{abstract}

Keywords: Robots, Mechatronic Systems, Structure, Dynamics, Dynamics Systems, Machines, Space, NASA, International Space Station

\section{Introduction}

Today, robots have not only penetrated to create microchips in electronics but also in medicine, where it helps to perform difficult operations, especially where precision is needed and the size is small and any human error could be fatal to the patient. Robots assist the doctor in heart, brain, kidney operations, not to mention bone implants and repair of damaged bones, cartilage and muscles. In this area, new materials adapted to the 
requirements of the human body also play an important role. The robotic systems used in today's operating blocks are very expensive and bulky and they need to be permanently adapted and prepared before a difficult operation, but in the end their help is unsurpassed because the operation takes place with the help of the machine and the computer, so they can perform a giant precision of hundredth of a millimeter, precision that stops the scalpel from cutting accidentally such as a nerve, a blood vessel, healthy tissue and anything else. Assisted operation brings infinitely more advantages than the disadvantage that the operator block is voluminous and costly. However, apart from the related space, the costs are amortized over time and the satisfaction of the successful operations is great for both the patients and the medical team. Surgery has taken advantage of this technology relatively late. Initial use of robots in surgery began in the late 1980s when an industrial robot was used to support instruments for stereotactic biopsy in neurosurgery. Also in the late 1980s, IBM built the first robot used in clinical practice, called Robo-doc. The first use of a robot in human surgery was for a transurethral prostate resection. In 1993, Computer Motion, Inc. introduced a voice-controlled arm, Automated Endoscopic System for Optimal Positioning (AESOPTM), used to support instruments, of optics in laparoscopic surgery. Its version, AESOPTM 2000 is the first humancontrolled robot approved by the Food and Drug Administration of the United States. In 1998, Reichenspurner introduced the ZEUS Microsurgical Robotic System into Germany. Today, the most complex and efficient robot in use is the daVinci system. With the birth of laparoscopy and information technology, surgery went into a new era. The development of surgical robots is primarily motivated by their desire the need to increase the effectiveness of surgical medical interventions. Medical actions are chosen based on information from various sources, including patient-specific data (vital signs and images of human body tissues and organs), general medical knowledge (atlases of human anatomy) and medical experiences. First, a robot can usually do things much more accurate than a man. This provides the first motivation for using CAD/CAM systems. Robots can be used successfully if the patient has been radiated (eg with X-radiation), thus not endangering the health of the medical team. Since ancient times, the imagination of mankind has been concerned with the idea of making cars equipped with artificial intelligence to execute operations similar to those performed by man. Technicians have been used for many years in various fields other than medical, such as the automotive industry, the underwater environment, the alien space, or the areas at risk of nuclear radiation.

A robot is a mechanic or virtually artificial engineer. The robot is a system composed of several elements: mechanical, sensors and actuators as well as a steering mechanism. The mechanics determine the appearance of the robot and the possible movements during operation. Sensors and actuators are used when interacting with the system environment. The targeting mechanism ensures that the robot accomplishes its goal successfully, for example by evaluating sensor information. This mechanism regulates the engines and plans the movements to be made. Robots with human form are called androids.

The basics of today's robots are far ahead. The first models of cars can be called automated (coming from the automated Greek, moving alone). They could do only one goal, being constrained by construction.

The Greek mathematician, Archytas, has, according to some accounts, built one of these automated primes: a propelled steamed pigeon that could fly alone. This wooden cavern was filled with air under pressure. It had a valve that allowed opening and closing by a counterweight. There have been many models over the centuries. Some made work easier and others served to people's amusement.

With the discovery of the 14th-century mechanical clock, new and complex possibilities have opened up. Not long afterward, the first machines appeared, which resembled the robots today. It was possible, however, that the movements followed one another without the need for manual intervention in that system.

The development of electro-technics in the twentieth century brought with it a development of robotics. Among the first mobile robots are the Elmer and Elsie system built by William Gray Walter in 1948. These tricycles could point to a light source and recognize collisions in the surroundings.

The year 1956 is considered as the birthday of the industrial robot. George Devol has applied this year in the US for a patent for "scheduled article transfer". A few years later he built together with Joseph Engelberger UNIMATE. This robot of approx. two tons was first introduced into the installation of TV iconoscopes and then found its way into the automotive industry. The programs for this robot were saved in the form of directional commands for motors on a magnetic cylinder. Since then, industrial robots as UNIMATE have been introduced in many production areas and are continually being developed to meet the complex demands that are required.

The heavy rise of robots in film and literature drew the attention of science to this type of machine. The scientific field, which deals with the construction of robots, is called robotics. The term was first used in 1942 by Isaac Asimov in his book Runaround. A general scientific theoretical field dealing with robots does not exist. These are mainly computer subdomains.

Most of the short stories of robots written by Asimov take place in the first epoch of positronic robotics and exploration of space. The special feature of robots in the 
Asimov universe is the Three Laws of Robotics, implanted in the positronic brain, to which all robots of the Asimovian fiction must obey, ensuring their submission to the creators.

Initially, the stories were not designed as a whole, the only common element being the positronic robots - there are inconsistencies especially between stories and novels. However, they all share the theme of interaction between humans, robots and morality. Some of the anthologized stories in Robot, Robot Stories and later gathered alongside other stories in the same series in The Complete Robot, do not seem to belong to the same universe with the Foundation and the Robots. "Involuntary Victory" features positronic robots that obey the Three Laws, but also an extraterrestrial civilization that lives on Jupiter. "To unite" includes humanoid robots, but they belong to a different future (in which the Cold War still unfolds) and the Three Laws are not mentioned.

The first four robot novels (Steel Caverns, Empty Sun, Aurora Robots and Robots and the Empire) form the Elijah Baley series, being police novels in which the earthly detective Elijah Baley and his partner humanoid robot Daneel Olivaw appear. Their action takes place hundreds of years after the stories, focusing on the conflict between the Spaniards - the descendants of human colonists on other planets - and the overpopulated people on the Earth. There are some exceptions. "Mirror Image," one of the stories in the Complete Robot anthology, takes place between the naked Sun and the Robots on Aurora) and includes both Baley and Olivaw. The "Earthland" story, featured in the Campbell Period anthology, describes the time when the worlds of the world decided to separate from Earth.

In 1993, writer Robert Silverberg expanded Asimov's story "The bicentennial man" to the size of a novel. In this book, there are a series of events related to the collection of stories Eu, the robot and Dr. Han Fastolfe recalls in Robots on Aurora about Andrew Martin, the main character of Asimov's story. Considering these aspects, one can also consider that this novel is in series.

Since the first of the robot novels were written before 1962, they did not receive SF prizes like Hugo, which was later. As far as the last two are concerned, they were written at a time when they could be rewarded with prizes. Robots on Aurora were nominated for the Hugo and Locus Awards in 1984, while Robots and the Empire were on the short list of Locus Awards for "Best Roman Science Fiction" in 1986.

A source of inspiration for Asimov was the Zoromes mechanic race from the story "The Jameson Satellite" written by Neil R. Jones in 1931.

Asimov read the story when he was 11 years old and mentioned it as a source of inspiration in the volume Before the Golden Age (1975), an anthology of the SF of the 1930s, in which Asimov relates the story of the SF he read during childhood and adolescence. As he himself says:
"Since the first appearance of the Zoromes mechanic in" The Jameson Satellite, "I came to the idea of benevolent robots that can serve people with decency, just as they did with Professor Jameson. These Zoromes are the spiritual ancestors of my "positronic robots," from Robbie to R. Daneel

Asimov integrated the Robots series into the most comprehensive series of the Foundation, bringing Daneel Olivaw back twenty thousand years later, in the time of the Galactic Empire, into the continuations and preludes of the original trilogy of the Foundation. In the last book of Robots-The Robots and the Empire-there is a story about how the worlds that later formed the Empire and how the Earth became a radioactive Earth.

Star Powder explicitly states that Earth has become radioactive following a nuclear war.

Asimov later solved the apparent inconsistency, explaining that this was the case in memory of the earthly people a few centuries after his party, the alteration of the information due to the loss of an important part of their planetary history.

One of the inconsistencies of the series is the method of producing energy on Earth. In the robot, the main method is that of the solar space stations, which have come to be overcome during the interview with Susan Calvin. On the other hand, in the Steel-Roman Caverns, whose action takes place hundreds of years after those in $\mathrm{Eu}$, the robot-the main source of energy is uraniumbased nuclear power stations, while solar space stations are confronted with issues that still can not be resolved. Subsequently, Robots and the Empire state that uranium is no longer used for a long time, nuclear fusion reactors have not been used for a long time, almost all of the energy coming from solar space stations.

Another incoherence is the development of the positronic brain. By the end of the book I, the robot appears "machines"-brains strong enough to calculate the consequences of people's actions and to recommend it on a global scale, even claiming that a human robot cannot be distinguished from a man at an external examination at least by a robot psychologist. On the other hand, the Elijah Baley series does not contain such magnitude positron creatures and humanoid robots are easily distinguished by humans.

In the naked Sun, one of the main elements of the intrigue is the ability of $\mathrm{R}$. Daneel to impersonate an aurora arriving on Solaria, without the solariums or robots realizing that he is, in fact, a humanoid robot. On the other hand, in the Robots on Aurora, Elijah Bailey and Daneel have an ample dialogue about the fact that no Spatial-robot can never mistake a humanoid robot of the type of Daniel with a true man because of the mechanical behavior and the manners of the robot.

The Foundation's Friends The Foundation's Friends included the following stories about positronic robots: 
"Balance" by Mike Resnick, "Pata" by Hal Clement, "Pappi" by Sheila Finch, "Plato cave" by Poul Anderson, "The Fourth Law of Robotics" by Harry Harrison and Robert Sheckley's "Caravan on the Asphalt Plate". Not all of these stories are in full compliance with Asimov's stories.

The anthology also included the story "The Challenge" written by Pamela Sargent, whose action takes place during the novels with Elijah Baley.

Shortly before his death in 1992, Asimov approved the project for three novels (Caliban, Inferno, Utopia) by Roger MacBride Allen, whose action takes place between the Robots and the Empire and the Galactic Empire Series.

The three novels tell the story of the Terraformation of the Inferno Space Sphere and of the robotic revolution that began with the creation of a Non-Law Robot and then of the Robots of the New Law.

There are other novels written by various authors (belonging to Robot's Isaac Asimov's Robots / Isaac Asimov's Robots in Time), poorly connected with the Robots Series, containing many contradictions with Asimov's books and not considered, in general, as belonging to the canon of the series.

In November 2009, Isaac Asimov's patrimony announced that the first novel of a trilogy about Susan Calvin, Robots and Chaos, written by fantasy author Mickey Zucker Reichert, is being prepared. The book appeared in November 2011 under the title "Robot: To Protect".

The first screening of Asimov's robot story was made during the third episode of the British television series Out of This World and was based on "A Robot Lost" (1962). In Leo Lehman's drama and having Maxine Audley in the role of Susan Calvin, this is the only episode of the series that still exists today.

It was followed in 1964 by the screening of the novel The Steel Caverns for the BBC Story Parade series, followed by four episodes for the TV series of BBC Out of the Unknown based on "Satisfaction Guaranteed" (1966), "Reasoning (in the episode" The (1969) and the naked sun (1969). In these screenings, Elijah Baley was interpreted by Peter Cushing (Steel Caverns) and Paul Maxwell (the naked sun), R. Daneel Olivaw by John Carson And David Collings and Susan Calvin by Beatrix Lehmann ("The Prophet") and Wendy Gifford (The Liar). In "Satisfaction Guaranteed," Susan Calvin's character was renamed Dr. Inge Jensen, being played by Ann Firbank.

Towards the late 1970s, Harlan Ellison wrote a script for Warner Bros based on Asimov I, the robot. The film's project was eventually abandoned, but Ellison's script was later published in Volume I, Robot: The Illustrated Screenplay (1994).

The 1988 Robots TV film is based on Asimov's Robot series and includes Stephen Rowe as Elijah Baley and Brent Barrett in R. Daneel Olivaw's.

"The Bicentennial Man" (1999) was the first adaptation for the big screen of a story or books by
Asimov and was based on both the original story of Asimov and the extension to the size of a Roman poster novel by Robert Silverberg. Role of Rob Andrew Martin was performed by Robin Williams.

Twentieth Century Fox's film I, the robot (2004), presented an original story that took place in the universe of Asimov, with Dr. Susan Calvin and other characters appearing in the stories collection I, the robot.

The film is based on a script written in 1995 by Jeff Vintar and entitled 'Hardwired'. While the original scenario did not have direct links with Asimov, it was sufficiently 'asymovian' (being a police story whose action was in a 'locked room' with robots as suspects) to provide a starting point a movie like me, the robot. Various elements of Asimov's stories were woven across the intrigue, including "A Robot Lost," "Avoiding Conflict," and "Robot Dreams." Will Smith played the role of Del Spooner and Bridget Moynahan and Susan Calvin.

Here we have to mention that all these SF writings and many others that have existed over time, especially in the 20th century, have influenced alongside obvious screenings, young people and not just them, to think more about our role, robots, into a better world. The robot's key role is to help the man make his work easier, safer, more enjoyable, just like a computerized machine that helps us work faster and better, the robot has an obvious role in making work easier, to work in our place when we are tired, when work is exhausting and repetitive, when the environment is toxic, hostile, dangerous and in many other situations.

However, it is time to say that the role of the robot in the future is altogether another, namely, to help us conquer the cosmic space to expand ourselves as a race in the whole universe in which we are now.

In fact, this is the robot's humanitarian role and in the future, it can be developed and prepared just for that purpose (Rulkov et al., 2016; Agarwala, 2016; Babayemi, 2016; Gusti and Semin, 2016; Mohamed et al., 2016; Wessels and Raad, 2016; Maraveas et al., 2015; Khalil, 2015; Rhode-Barbarigos et al., 2015; Takeuchi et al., 2015; Li et al., 2015; Vernardos and Gantes, 2015; Bourahla and Blakeborough, 2015; Stavridou et al., 2015; Ong et al., 2015; Dixit and Pal, 2015; Rajput et al., 2016; Rea and Ottaviano, 2016; Zurfi and Zhang, 2016 a-b; Zheng and Li, 2016; Buonomano et al., 2016 a-b; Faizal et al., 2016; Ascione et al., 2016; Elmeddahi et al., 2016; Calise et al., 2016; Morse et al., 2016; Abouobaida, 2016; Rohit and Dixit, 2016; Kazakov et al., 2016; Alwetaishi, 2016; Riccio et al., 2016 a-b; Iqbal, 2016; Hasan and El-Naas, 2016; AlHasan and Al-Ghamdi, 2016; Jiang et al., 2016; Sepúlveda, 2016; Martins et al., 2016; Pisello et al., 2016; Jarahi, 2016; Mondal et al., 2016; Mansour, 2016; Al Qadi et al., 2016b; Campo et al., 2016; Samantaray et al., 2016; Malomar et al., 2016; Rich and Badar, 2016; Hirun, 2016; Bucinell, 2016; Nabilou, 2016b; Barone et al., 2016; Chisari and Bedon, 2016; Bedon and Louter, 2016; Santos and Bedon, 2016; Minghini et al., 2016; 
Bedon, 2016; Jafari et al., 2016; Chiozzi et al., 2016; Orlando and Benvenuti, 2016; Wang and Yagi, 2016; Obaiys et al., 2016; Ahmed et al., 2016; Jauhari et al., 2016; Syahrullah and Sinaga, 2016; Shanmugam, 2016; Jaber and Bicker, 2016; Wang et al., 2016; Moubarek and Gharsallah, 2016; Amani, 2016; Shruti, 2016; Pérezde León et al., 2016; Mohseni and Tsavdaridis, 2016; Abu-Lebdeh et al., 2016; Serebrennikov et al., 2016; Budak et al., 2016; Augustine et al., 2016; Jarahi and Seifilaleh, 2016; Nabilou, 2016a; You et al., 2016; AL Qadi et al., 2016a; Rama et al., 2016; Sallami et al., 2016; Huang et al., 2016; Ali et al., 2016; Kamble and Kumar, 2016; Saikia and Karak, 2016; Zeferino et al., 2016; Pravettoni et al., 2016; Bedon and Amadio, 2016; Chen and $\mathrm{Xu}, 2016$; Mavukkandy et al., 2016; Yeargin et al., 2016; Madani and Dababneh, 2016; Alhasanat et al., 2016; Elliott et al., 2016; Suarez et al., 2016; Kuli et al., 2016; Waters et al., 2016; Montgomery et al., 2016; Lamarre et al., 2016; Daud et al., 2008; Taher et al., 2008; Zulkifli et al., 2008; Pourmahmoud, 2008; Pannirselvam et al., 2008; $\mathrm{Ng}$ et al., 2008; El-Tous, 2008; Akhesmeh et al., 2008; Nachiengtai et al., 2008; Moezi et al., 2008; Boucetta, 2008; Darabi et al., 2008; Semin and Bakar, 2008; Al-Abbas, 2009; Abdullah et al., 2009; Abu-Ein, 2009; Opafunso et al., 2009; Semin et al., 2009 a-c; Zulkifli et al., 2009; Marzuki et al., 2015; Bier and Mostafavi, 2015; Momta et al., 2015; Farokhi and Gordini, 2015; Khalifa et al., 2015; Yang and Lin, 2015; Chang et al., 2015; Demetriou et al., 2015; Rajupillai et al., 2015; Sylvester et al., 2015a; AbRahman et al., 2009; Abdullah and Halim, 2009; Zotos and Costopoulos, 2009; Feraga et al., 2009; Bakar et al., 2009; Cardu et al., 2009; Bolonkin, 2009 a-b; Nandhakumar et al., 2009; Odeh et al., 2009; Lubis et al., 2009; Fathallah and Bakar, 2009; Marghany and Hashim, 2009; Kwon et al., 2010; Aly and Abuelnasr, 2010; Farahani et al., 2010; Ahmed et al., 2010; Kunanoppadon, 2010; Helmy and El-Taweel, 2010; Qutbodin, 2010; Pattanasethanon, 2010; Fen et al., 2011; Thongwan et al., 2011; Theansuwan and Triratanasirichai, 2011; Al Smadi, 2011; Tourab et al., 2011; Raptis et al., 2011; Momani et al., 2011; Ismail et al., 2011; Anizan et al., 2011; Tsolakis and Raptis, 2011; Abdullah et al., 2011; Kechiche et al., 2011; Ho et al., 2011; Rajbhandari et al., 2011; Aleksic and Lovric, 2011; Kaewnai and Wongwises, 2011; Idarwazeh, 2011; Ebrahim et al., 2012; Abdelkrim et al., 2012; Mohan et al., 2012; Abam et al., 2012; Hassan et al., 2012; Jalil and Sampe, 2013; Jaoude and El-Tawil, 2013; Ali and Shumaker, 2013; Zhao, 2013; El-Labban et al., 2013; Djalel et al., 2013; Nahas and Kozaitis, 2013; Petrescu and Petrescu, 2014 a-i, 2015 a-e, 2016 a-d; Fu et al., 2015; Al-Nasra et al., 2015; Amer et al., 2015; Sylvester et al., 2015b; Kumar et al., 2015; Gupta et al., 2015; Stavridou et al., 2015b; Casadei, 2015; Ge and Xu, 2015; Moretti, 2015; Wang et al., 2015; Antonescu and Petrescu, 1985; 1989; Antonescu et al., 1985a; 1985b; 1986; 1987; 1988; 1994; 1997; 2000a; 2000b; 2001; Aversa et al., 2017a; 2017b; 2017c; 2017d; 2017e; 2016a; 2016b; 2016c; 2016d; 2016e; 2016f; 2016g; 2016h; 2016i; 2016j; 2016k; 20161; 2016m; 2016n; 2016o; Cao et al., 2013; Dong et al., 2013; Comanescu, 2010; Franklin, 1930; He et al., 2013; Lee, 2013; Lin et al., 2013; Liu et al., 2013; Padula and Perdereau, 2013; Perumaal and Jawahar, 2013; Petrescu, 2011; 2015a; 2015b; Petrescu and Petrescu, 1995a; 1995b; 1997a; 1997b; 1997c; 2000a; $2000 \mathrm{~b} ; 2002 \mathrm{a} ; 2002 \mathrm{~b} ; 2003 ; 2005 \mathrm{a} ; 2005 \mathrm{~b} ; 2005 \mathrm{c}$; $2005 \mathrm{~d} ; 2005 \mathrm{e} ; 2011 \mathrm{a} ; 2011 \mathrm{~b} ; 2012 \mathrm{a} ; 2012 \mathrm{~b} ; 2013 \mathrm{a}$; 2013b; 2013c; 2013d; 2013e; 2016a; 2016b; 2016c; Petrescu et al., 2009; 2016; 2017a; 2017b; 2017c; 2017d; $2017 \mathrm{e} ; 2017 \mathrm{f} ; 2017 \mathrm{~g} ; 2017 \mathrm{~h} ; 2017 \mathrm{i} ; 2017 \mathrm{j} ; 2017 \mathrm{k}$; 2017l; 2017m; 2017n; 2017o; 2017p; 2017q; 2017r; $2017 \mathrm{~s} ; 2017 \mathrm{t} ; 2017 \mathrm{u} ; 2017 \mathrm{v} ; 2017 \mathrm{w} ; 2017 \mathrm{x} ; 2017 \mathrm{y}$; 2017z; 2017aa; 2017ab; 2017ac; 2017ad; 2017ae; 2018a; 2018b; 2018c; 2018d; 2018e; 2018f; 2018g; 2018h; 2018i; 2018j; 2018k; 20181; 2018m; 2018n).

\section{Materials and Methods}

Artificial intelligence is part of computer science and represents the study and design of intelligent agents that understand the environment and take action.

John McCarthy, who founded the idea in 1956, defines artificial intelligence as "science and intelligence engineering."

The big challenge is to build an intelligent car like a Homo Sapiens. This aspect raises philosophical problems about the nature of the mind and the scientific boundaries, problems transmitted through fiction and philosophy since antiquity.

Artificial intelligence is treated by many with skepticism, claiming that it will not be possible to create a smart robot like a human.

A smart robot must have the ability to deduce, rationalize and solve the problems encountered. We will have to develop a human brain-like mechanism to represent knowledge. Such a robot must have the ability to plan, learn, process natural language, represent and call upon the knowledge already acquired. They will have to "have" creative intelligence, create new concepts and ideas and, last but not least, have self-consciousness.

And as the cognitive psyche is not enough, we are still challenging: designing the emotional psyche. Such a robot will have feelings, basically ... will live in his own way.

The ability to plan is essential. This will help the robot to propose some goals and then try to meet them. The robot will need to be able to visualize the future and take action to improve the way to reach that goal. This requires predictions about how his actions will change the future.

In planning issues, the robot will have to reverify periodically if its predictions have come true and, where appropriate, take new decisions. Joint planning is another aspect and involves more robots. 
Robots must be able to plan events. Algorithms have been written to create puzzles, play various games, or logical deductions. Logic is not too difficult to translate into a programming language. Methods were made in which software programs were dealing with unreliable or incomplete information and the deduction was required.

But for hard problems these algorithms require enormous resources, the time to solve it and the necessary memory have become astronomical figures. And here, there is a need for more efficient methods.

Knowledge representation is another central theme in the research of artificial intelligence.

Here we are struck by another problem. A robot must represent objects, properties, categories and relationships between objects, situations, events, etc. Knowing the surrounding world becomes a problem.

Although at the base, the mechanisms of a single neuron are known and are quite similar to the logic gates in a computing system, there are differences in storing information. As a structure, computer memory is not relational. We will have to make a program to make it that way.

The robot must be able to learn. Learning is an essential process in the evolution and development of intelligence. In the human brain, the information from the outside is memorized in relation to the already existing ones. We notice that an idea that contains already known elements can be saved more easily than another that contains unknown things until then. In order to memorize an idea more easily, we must link it mentally to another, with well-fixed roots, with elements already known.

Learning not only involves memorizing raw information but also consciousness and understanding. Otherwise, this information will not be of any help.

This gives cars the ability to read and understand people's language. It is extremely necessary for communicating with people. Progress has been made in this area, but far from being perfection

The robot must be able to manipulate the objects around it. He has to look for, locate objects, create maps of the environment and plan his movements in space.
Perception is the ability of robots to use information obtained from the sensors (cameras, microphones, sonar and other devices) to deduce aspects of the world around. But there are major issues in recognizing objects, their human voice and their faces

Exploratory robots are robots that operate in hard-toreach and dangerous locations, telegraph or partially autonomous. They can work for example in a region in military conflict, on the Moon or on Mars. A geared navigation on the ground in the last two cases is impossible due to distance. Communication signals arrive at their destination in a matter of hours and their reception lasts as long. In such situations, robots have to be programmed with several types of behavior, from which they choose the most appropriate and execute it.

This type of robot equipped with sensors was also used to research pyramid wells. Several cryobots (cryo robots) have already been tested by NASA in Antarctica. This type of robot can reach up to $3,600 \mathrm{~m}$ through the ice. Cryobots can thus be used in polar head research on Mars and Europe in the hope of alien living.

\section{Results and Discussion}

Astronauts live and work in orbit and the Houston Mission Control Center practically never sleeps. The International Space Station (Fig. 1-6) is a permanent space colony, inaugurated one year before the iconic film 2001: Space Odyssey.

We remain fascinated by the possibilities, discoveries and travels in space. Especially Sci-Fi. The 2013 Gravity movie with Sandra Bullock and George Clooney brought hundreds of millions of dollars to a box office and won seven Academy Awards. And the movie Life (2017) is a great one. But we are indifferent to what is happening in reality. Without the fanfare, I entered the era of Captain Kirk and Spock. We know fictional characters better than real ones. Perhaps not surprising, everyday life on the station does not have the drama of a film script, but we will try to find out in this article how to live in space for six months.

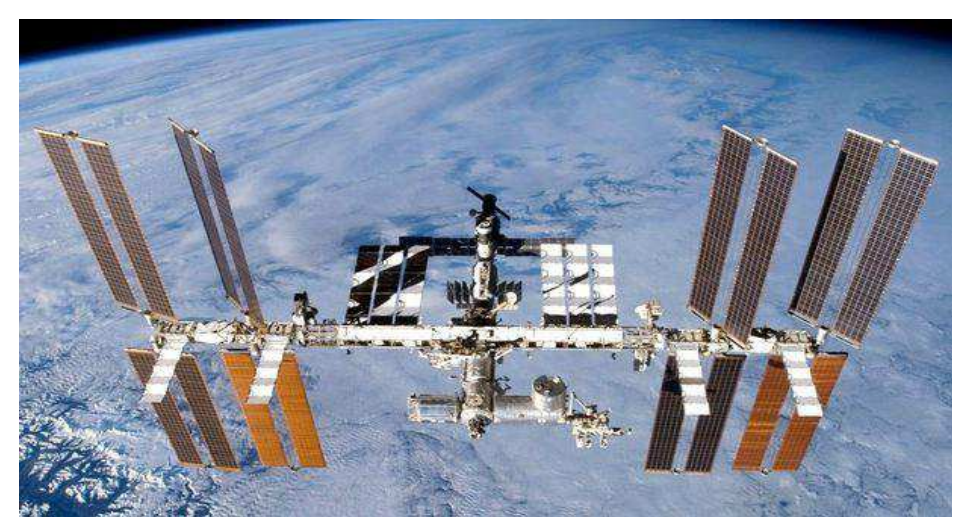

Fig. 1: The international space station 

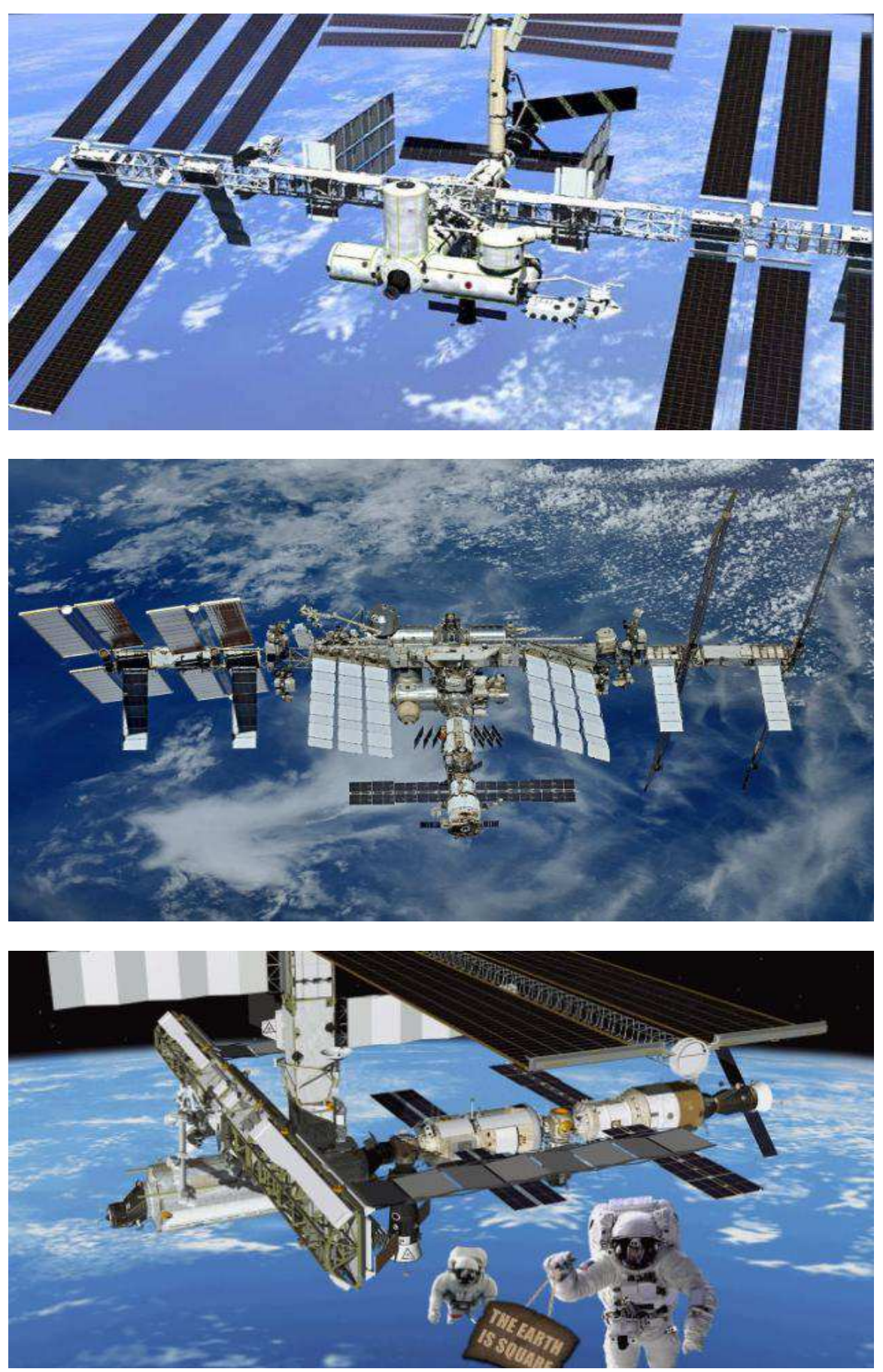

Fig. 2: The international space station

The International Space Station is a huge outpost. From the edge of a solar panel to the edge of the opposite, the station measures as much a football pitch and weighs about 450 tons. It is so great that it can be seen with the naked eye at night. This is also due to low orbit at an altitude that varies between $319.6 \mathrm{~km}$ and $346.9 \mathrm{~km}$. Orbital speed is $7.67 \mathrm{~km} / \mathrm{s}$, or $27,600 \mathrm{~km} / \mathrm{h}$. An orbit (rotation around the Earth) lasts for 92.65 minutes and one day the station takes an Earth detour 15.54 times.

Five major space agencies are participating in this project: NASA (USA), RKA (Russia), JAXA (Japan), CSA (Canada) and ESA (European Spatial Agency). The responsibilities of the station's navigation and operation are shared and the role of the station commander alternates between Americans and Russians. American 
and Russian astronauts work in their own modules, but crews often gather for meals after work hours.

The space station is both a space ship and a home. He has his own personality, with good and bad things. Crew members come and go, bringing their own style, but the station itself imposes a certain rhythm and tone. It has a much more sophisticated system of water recycling than on Earth. An astronaut who mixes an orange drink for breakfast on Monday morning and urinates in the afternoon can use the same purified water to make a fresh drink for Thursday. However, the station does not have a refrigerator or freezer for food (there is a freezer for scientific experiments). Even though the food is much better than 20 years ago, most of it is still vacuum or canned. The arrival of some oranges every two months on the ship is a reason to party.

In 2009, with the expansion of the International Space Station, the US has installed some private cabinets. Here astronauts can sleep and enjoy for hours of intimacy and quiet, away from video cameras. Each cabin is upholstered in white material and equipped with a sleeping bag attached to an interior wall.

Mike Hopkins, who has "lived" on the International Space Station for 6 months, says that "on Earth when I had a long day, when mentally and physically tired and stretching on my bed, there was a feeling of relief. You get a load on your feet and you immediately feel relaxed. In space, you never feel that. You never have the feeling of taking your weight off your feet."
Some astronauts bind with some strings to somehow feel like they are lying in a bed. "The astronauts who let their arms out of their sleeping bag, float freely and look like bald dancers," says Hopkins.

Hopkins says he does not have unusual dreams in space, although now back to Earth, he sometimes dreams of floating through the station.

On the station, even the ordinary becomes strange. Exercise Bike for American astronauts has no handlebars. Nor does it have it. Without gravity, you can watch a movie while pedaling, letting your laptop float wherever you want.

Astronauts had to be careful not to stay in one place for too long. Without gravity to help circulate the air, expired carbon dioxide tends to form a cloud around the head and can lead to headaches. The station is today equipped with fans to meet this problem.

Since the first components have been released, 216 men and women have lived on the station and NASA has learned a lot about how you can live in space - about the difference in the transition from gravity to zero-G and how to survive months without gravity.

Life on the station does not look like anything on Earth. It's more exciting. And when astronauts go out into space, it can be thrilling and dangerous at the same time. Space is a cold and unforgiving place - a wrong maneuver can trigger a disaster. NASA has returned the risk by writing procedures for almost anything. From replacing a water filter up to the safety checks of a space suit.

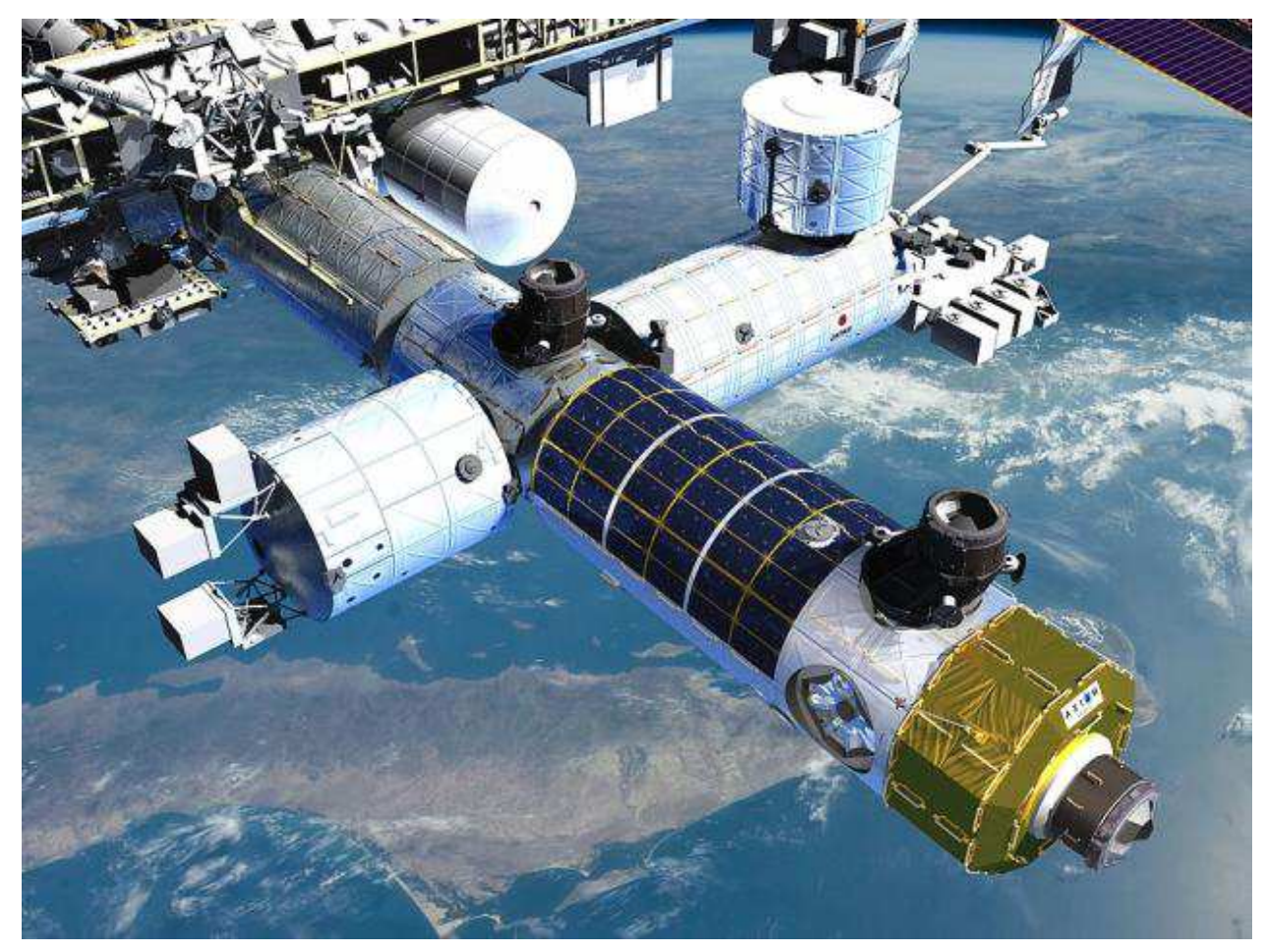

Fig. 3: The international space station 

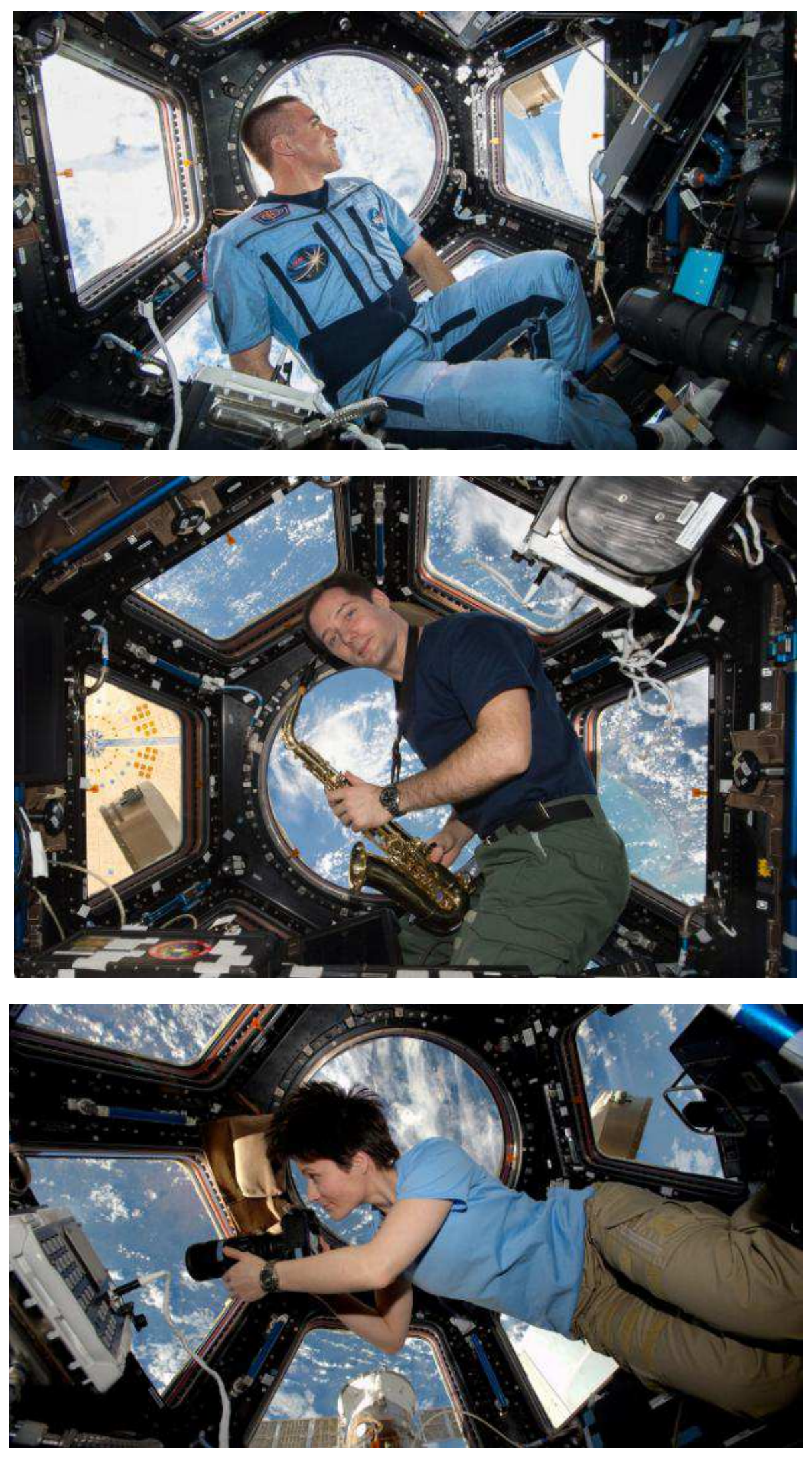

Fig. 4: The international space station 

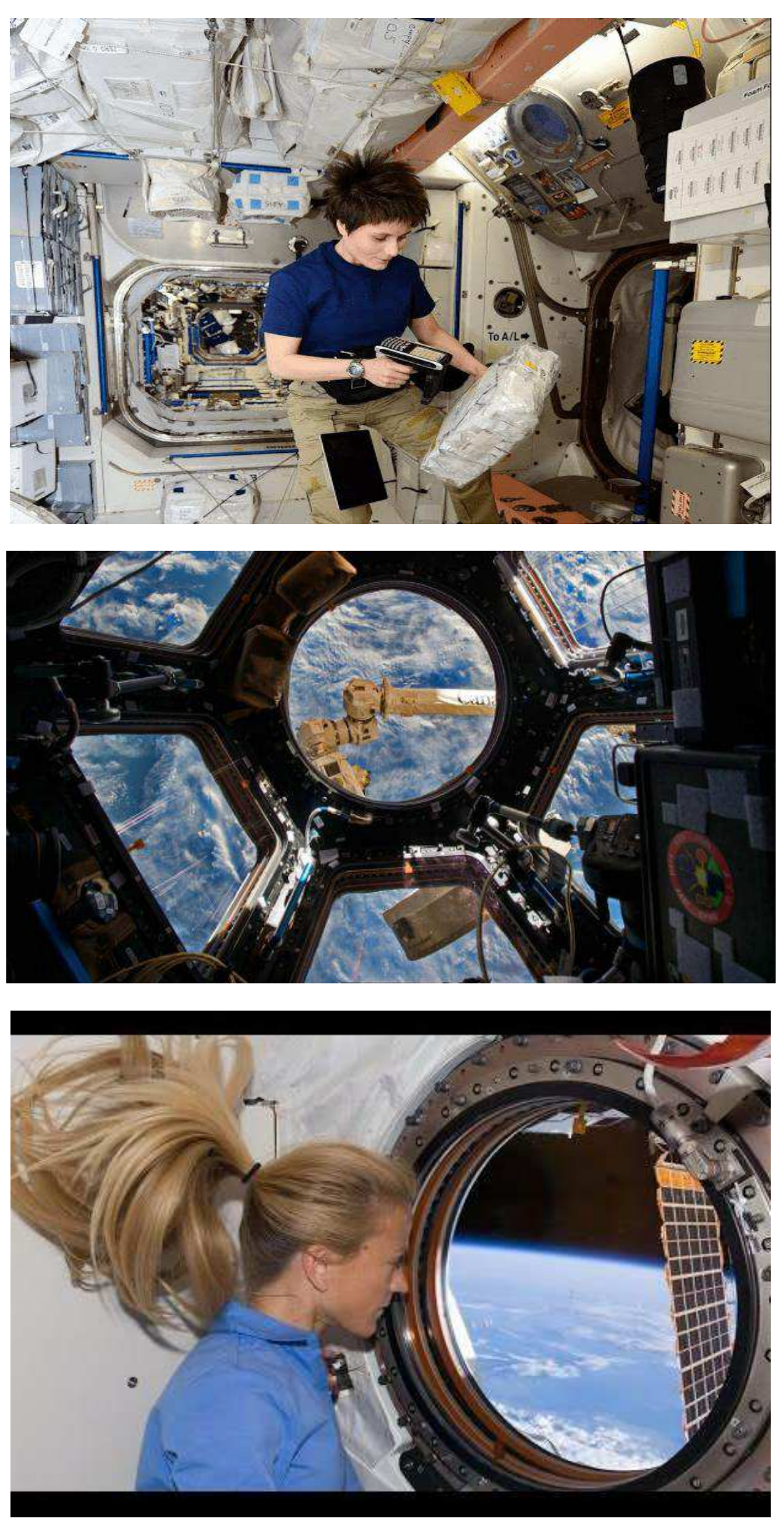

Fig. 5: The international space station 

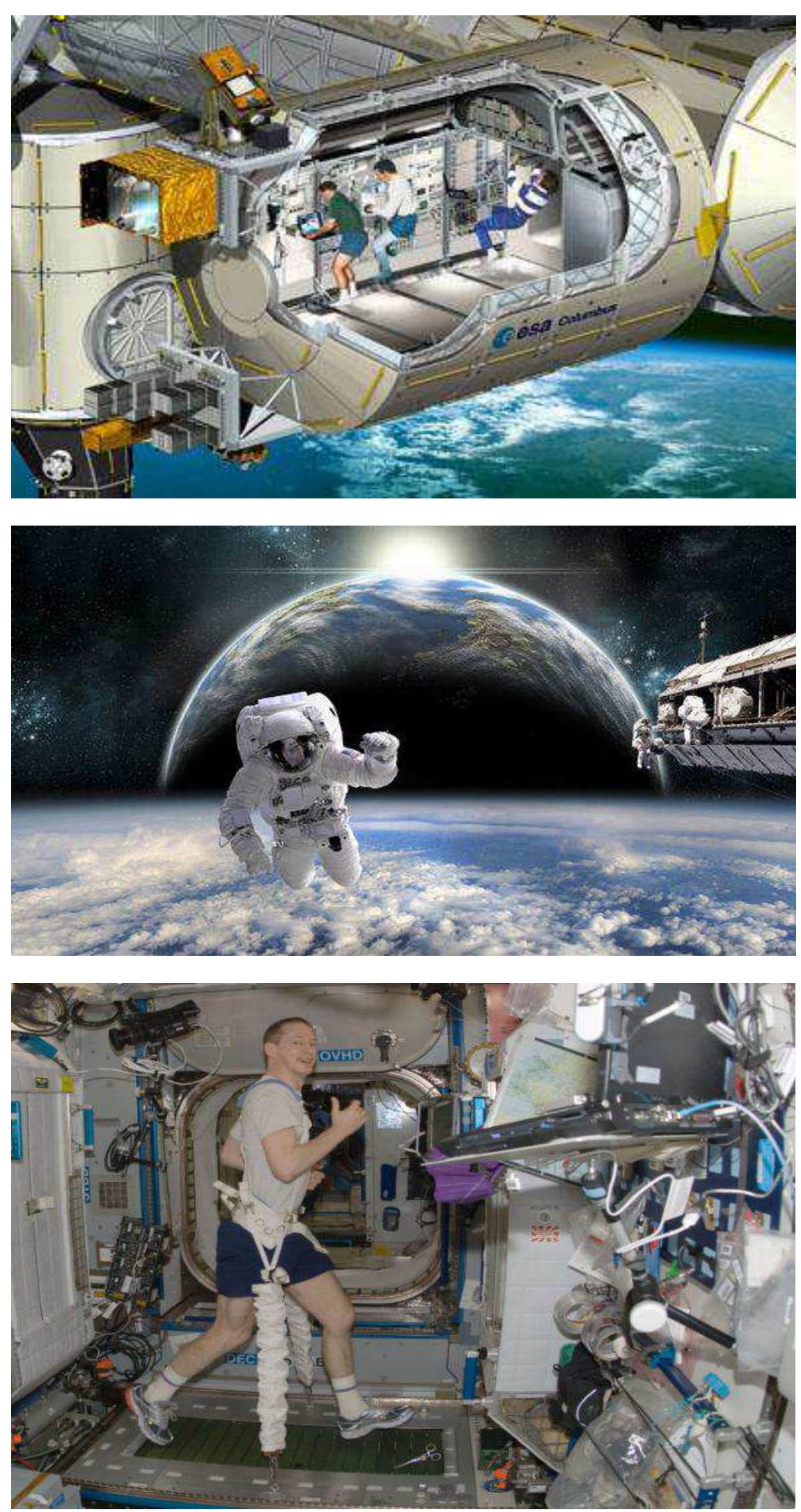

Fig. 6: The international space station 
In 60 years of space, NASA suffered three fatal accidents in which 17 people died: the Apollo 1 capsule fired in 1967, Challenger was destroyed in 1986 and the last, the Columbia ship exploded in 2003. But neither one of these accidents did not happen due to astronauts.

Just after the slightest estimates, the International Space Station costs about \$350,000 per hour, which makes astronauts time a very expensive resource. For this reason, astronauts start working at 7: 30 in the morning and end at 19:00. Even on weekends, they are not free, Saturday is devoted to cleaning the station and on Sunday, inevitably, some work appears.

From 2003 to 2010, 10 US astronauts living on the station had a diary in a research study by Jack Stuster, an anthropologist who studies people living in extreme environments. Anonymous diaries reveal people who are excited about living in space and occasionally bored and sometimes seriously irritated.

"I laughed alone today reading the procedures," wrote an astronaut. "To replace a bulb, I needed to have safety glasses and a vacuum cleaner at my fingertips. That's what happens if the bulb breaks. However, the bulb itself is encapsulated in a plastic case, so even if the bottle breaks, the shards will not be scattered. I also had to take a picture of the bulb installed before it started. Why? I have no idea! It's just how NASA is doing. "

"Astronauts never get tired of looking at the Earth" wrote an astronaut. He was so captivated that he looked through the window an entire Earth orbit. "I looked at Earth from the point of view of an alien visitor," wrote another astronaut. "Where would I land and how would I first contact people?"

Writing in the diary shows very clearly that six months is a long period of time-without families and without friends, without fresh food, without feeling wind, rain or pleasure of gravity. A long period of time in which you are in charge of maintaining the station. Records also show that keeping a journal significantly improves the morale of an astronaut.

During short missions, the enthusiasm of being in space does not diminish. On the station, however, NASA had to be more attentive to the morale of astronauts, because it is a lot of work and most of the time uninteresting. The International Space Station has a phone call from where astronauts can call who they want. Astronaut families receive tablets for private video conferencing. And astronauts have private conversations with NASA psychologists once every two weeks.

In space, says Mike Hopkins, "everything is new. From hygiene, supper to rest, everything is completely different." This is the opinion of someone who was trained every day two years before launch.

"How would we live in zero gravity?" Asks Sandra Magnus, who took part in 3 space flights, including 130 days per station. "It's really fun," she says, then bursts into laughter. "I learned to transport my things with my knees. That way I had my hands to move. Gravity is an indispensable tool and you do not appreciate it until you have to live without it. Look around the room you're in ... there's stuff sitting on the tables, on the shelves, in the drawers, on the floor. In space, all this would be everywhere. Every object you use must be caught or it will float. " Astronauts spend enough time looking for lost gear. "Tracking things can eat all day," says astronaut Mike Fincke.

Sandra Magnus liked to cook for colleagues on the station, finding new dishes from the ingredients sent by NASA. "To cook it takes good hours, so I could only cook over the weekend," says Sandra. "Why? Think of one thing: when you cook, you'll throw the scrap into the garbage. The station can not. We used a piece of adhesive tape, but even so, cooking took a lot longer."

Mike Fincke spent more time in space than any other American - 381 days in 3 missions. He made nine exits in space, cumulating a total of 48 hours. Mike studied at MIT and Standford and graduated from the U.S. Air Force Test Pilot School before becoming an astronaut.

"A little push with your big toe and you'll walk half of the station. It's like you're a Superman, "says Mike Fincke.

\section{How Does It Affect Health?}

Under zero gravity conditions, all body fluids are also in zero gravity, so astronauts often have a feeling of clutter.

Lack of gravity causes nausea. 54-year-old Leroy Chiao retired after four flights and described what was going on just before leaving the chair. "Your inner ear thinks you are overturning. The feeling of balance is everywhere ... Meanwhile, your eyes tell you that you will not roll, stand in a vertical position. The two systems send all this contradictory information to your brain. This can be disturbing, for this reason, some astronauts feel nauseated. "After the first days - really difficult for astronauts - they learn to ignore the panic of the inner ear and" space disease "disappears.

Astronauts lose bone mass, but they regenerate in part in response to the exercises that they do every day. Without gravity, the rate at which cells revert slows down and thin bones weaken.

Mark Guilliams is NASA's main coach for NASA astronauts. He works at the Johnson Center in Houston where he has over 40 active American astronauts.

"Life in zero gravity is the equivalent of a prolonged stay in a hospital," says Guilliams. "You lose muscle, you lose the volume of blood."

"Without gravity, sweating is not pleasant. On Earth, when you ride a bicycle, sweat runs out of you. Upon the station, sticks to you, around your arms, your head, around your eyes."

The attention to fitness is equally important in terms of science and the future, as it is about keeping an astronaut in a healthy state. NASA is worried about two things: recovery time when astronauts return home and 
maintain fitness for two years or more as they would take to make a round trip on Mars. If astronauts lose $10 \%$ of cardio, how much does their life be affected on the station? "Not too much," says Guilliams, "but if we go to Mars, that loss could be critical."

We still do not understand all the implications of a long flight. "Five years ago," says John Charles, a NASA researcher within the Human Research Program, "I had an astronaut on the station saying suddenly," hey, my ability to see has changed. They are 3 months old and cannot read the checklists anymore. "It seems Charles says that all the fluid that moves up increases the intracranial pressure. The fluid pushes back the eyeball and flattens it, "says Charles.

Today the station is equipped with adjustable glasses, so astronauts who do not normally wear glasses, use them if they need it. For those who already wear glasses, additional eyeglasses with stronger prescriptions are brought.

Astronauts need a good view and vision damage during space flight is not a minor problem. NASA knew about the problem several decades ago. "We also saw this on Skylab" - the first space station in the US, which hosted more astronauts for 1-3 months between 19731974. Bone mass, muscle mass, blood volume, etc all return to normal for the most part. But astronaut's eyes do not recover completely. Even physicians do not know exactly what would happen during a mission four or five times longer than today.

The station is a permanent outpost, but it is not independent. Those at the Control Center do not wake the astronauts from sleep and the control of the station is from the ground.

Each day begins and ends with a planning conference, during which astronauts check with all five control centers in the world the program grids, maintenance, or what will be done the next day. NASA has a second unit in Huntsville, Alabama, which deals with scientific research. Moscow has a mission control center for half of the Russian station and the European Space Agency and Japan's Space Agency have their own control centers.

Although the station is flying at $27,600 \mathrm{~km} / \mathrm{h}$. (10 times faster than a bullet), still can not escape the daily sessions.

Even if astronauts live and work on the station, they do not control the flight. The Houston and Moscow centers are in charge of piloting the station where the mission control center monitors the position and adjusts it as needed using gyroscopes and propulsion engines. The mission control center also monitors all onboard systems - electrical, life support, IT, communications. It takes about 1,000 people on Earth for every astronaut on the orbit. Even after the astronauts finish their workday, those on Earth continue to work shifts 24 hours a day.

Life on the station is managed at a minute. When an astronaut clicks on a time cell, it expands and shows the steps required to perform the specific task.
In its way, the program can be a source of freedom, but it can also be frustrating. Scientific experiments, maintenance tasks, the arrival and departure of the foodbringing vehicle, everything is fixed from the ground. Each astronaut's program has a red line that slowly moves to the laptop screen, from left to right, showing the current time and what it should do at the time.

Life in space is so complicated that 50 employees are only needed to build the program for the American astronauts in orbit. From fun and intellectually challenging tasks (doing research with ground scientists) to boring ones (recording serial numbers of items in the trash before sending them to be burned in the atmosphere) all are part of the daily work of an astronaut in space.

\section{Exit in Space}

The costume is not less than $50 \mathrm{~kg}$ and on Earth, during simulations, 3-4 people are needed. The station is just one. The equipping procedure to get into space has not less than 400 steps.

An extravehicular activity is for almost all astronauts, the greatest challenge. Outside the station, you are an independent astronomical body that orbits $27,600 \mathrm{~km} / \mathrm{h}$.

Extravehicular activity is dangerous and shows how dangerous space can be. A single connector could lead to disaster. That's why space drives are simulated on Earth in a swimming pool and are carefully planned.

NASA initially promised that space shuttles will fly at least 25 times a year. In fact, the transfer program had a duration of five flights a year. In the peak year, in 1985, there were 5 flights. President Ronald Reagan, in his 1984 Statement on the Statute of the Union, has commissioned NASA to permanently create and hire a space station that he predicted would allow him to leap into scientific research, communications and drugs that could only be fabricated space-bar. NASA's original vision for the station was as ambitious as Apollo. The station was supposed to have seven main functions: to be a research laboratory, a production unit, an observatory, a space transport center, a satellite repair facility, a spacecraft assembling station and a stationary base for missions in the Solar System.

30 years later, only one of these functions remained: the research lab. And despite Reagan's aspirations, nobody today uses materials or drugs invented on the station. Currently, about $40 \%$ of the station's commercial research capacity is not used - most likely because some companies do not know it is available.

NASA has always said that understanding how to live and work in space for long periods of time has been a key goal of the International Space Station. But, from the White House, it may seem expensive this race around the Earth, considering that the mission costs about $\$ 8$ million a day. 
Space makes us anxious. We are anxious that things go smoothly as if space flight should be infallible like a flight to London. And we are looking forward to a return on investment.

We fly in space because of human ambition, because nothing gives us more resistance than trying to do what we have not done before. And we're flying in space because space is the eighth continent.

We may eventually need asteroid or lunar resources, depending on how we manage the resources we have here on Earth. Eventually, we should become a species that will conquer other planets, whether we are no longer inside or that we actually destroy it or it will be destroyed.

\section{Conclusion}

Life in space is so complicated that 50 employees are only needed to build the program for the American astronauts in orbit. From fun and intellectually challenging tasks (doing research with ground scientists) to boring ones (recording serial numbers of items in the trash before sending them to be burned in the atmosphere) all are part of the daily work of an astronaut in space.

However, it is time to say that the role of the robot in the future is altogether another, namely, to help us conquer the cosmic space to expand ourselves as a race in the whole universe in which we are now. In fact, this is the robot's humanitarian role and in the future, it can be developed and prepared just for that purpose. Exploratory robots are robots that operate in hard-toreach and dangerous locations, telegraph or partially autonomous. They can work for example in a region in military conflict, on the Moon or on Mars.

A geared navigation on the ground in the last two cases is impossible due to distance. Communication signals arrive at their destination in a matter of hours and their reception lasts as long. In such situations, robots have to be programmed with several types of behavior, from which they choose the most appropriate and execute it. This type of robot equipped with sensors was also used to research pyramid wells. Several cryobots (cryo robots) have already been tested by NASA in Antarctica. This type of robot can reach up to $3,600 \mathrm{~m}$ through the ice. Cryobots can thus be used in polar head research on Mars and Europe in the hope of alien living.

NASA has always said that understanding how to live and work in space for long periods of time has been a key goal of the International Space Station. But, from the White House, it may seem expensive this race around the Earth, considering that the mission costs about $\$ 8$ million a day.

Space makes us anxious. We are anxious that things go smoothly as if space flight should be infallible like a flight to London. And we are looking forward to a return on investment.
We fly in space because of human ambition, because nothing gives us more resistance than trying to do what we have not done before. And we're flying in space because space is the eighth continent.

We may eventually need asteroid or lunar resources, depending on how we manage the resources we have here on Earth. Eventually, we should become a species that will conquer other planets, whether we are no longer inside or that we actually destroy it or it will be destroyed.

\section{Acknowledgement}

This text was acknowledged and appreciated by Dr. Veturia CHIROIU Honorific member of Technical Sciences Academy of Romania (ASTR) PhD supervisor in Mechanical Engineering.

\section{Funding Information}

Research contract: 1-Research contract: Contract number 36-5-4D/1986 from 24IV1985, beneficiary CNST RO (Romanian National Center for Science and Technology) Improving dynamic mechanisms.

2-Contract research integration. 19-91-3 from 29.03.1991; Beneficiary: MIS; TOPIC: Research on designing mechanisms with bars, cams and gears, with application in industrial robots.

3-Contract research. GR 69/10.05.2007: NURC in 2762; theme 8: Dynamic analysis of mechanisms and manipulators with bars and gears.

4-Labor contract, no. 35/22.01.2013, the UPB, "Stand for reading performance parameters of kinematics and dynamic mechanisms, using inductive and incremental encoders, to a Mitsubishi Mechatronic System" "PN-IIIN-CI-2012-1-0389".

All these matters are copyrighted! Copyrights: 394qodGnhhtej, from 17-02-2010 13:42:18; 463vpstuCGsiy, from 20-03-2010 12:45:30; 631sqfsgquutm, from 24-05-2010 16:15:22; 933CrDztEfqow, from 07-01-2011 13:37:52.

\section{Ethics}

This article is original and contains unpublished material. Authors declare that are not ethical issues and no conflict of interest that may arise after the publication of this manuscript.

\section{References}

Abam, F.I., IU. Ugot and D.I. Igbong, 2012. Performance analysis and components irreversibilities of a $(25 \mathrm{MW})$ gas turbine power plant modeled with a spray cooler. Am. J. Eng. Applied Sci., 5: 35-41.

DOI: 10.3844/ajeassp.2012.35.41 
Abdelkrim, H., S.B. Othman, A.K.B. Salem and S.B. Saoud, 2012. Dynamic partial reconfiguration contribution on system on programmable chip architecture for motor drive implementation. Am. J. Eng. Applied Sci., 5: 15-24.

DOI: 10.3844/ajeassp.2012.15.24

Abdullah, H. and S.A. Halim, 2009. Electrical and magnetoresistive studies Nd doped on La-Ba-MnO3 manganites for low-field sensor application. Am. J. Eng. Applied Sci., 2: 297-303. DOI: 10.3844/ajeassp.2009.297.303

Abdullah, M., A.F.M. Zain, Y.H. Ho and S. Abdullah, 2009. TEC and scintillation study of equatorial ionosphere: A month campaign over sipitang and parit raja stations. Malaysia, Am. J. Eng. Applied Sci., 2: 44-49. DOI: 10.3844/ajeassp.2009.44.49

Abdullah, M.Z., A. Saat and Z. Hamzah, 2011. Optimization of energy dispersive X-ray fluorescence spectrometer to analyze heavy metals in moss samples. Am. J. Eng. Applied Sci., 4: 355-362. DOI: 10.3844/ajeassp.2011.355.362

Abouobaida, H., 2016. Robust and efficient controller to design a standalone source supplied DC and AC load powered by photovoltaic generator. Am. J. Eng. Applied Sci., 9: 894-901.

DOI: 10.3844 /ajeassp.2016.894.901

Ab-Rahman, M.S., H. Guna, M.H. Harun, S.D. Zan and K. Jumari, 2009. Cost-effective fabrication of self-made $1 \times 12$ polymer optical fiber-based optical splitters for automotive application. Am. J. Eng. Applied Sci., 2: 252-259. DOI: 10.3844/ajeassp.2009.252.259

Abu-Ein, S., 2009. Numerical and analytical study of exhaust gases flow in porous media with applications to diesel particulate filters. Am. J. Eng. Applied Sci., 2: 70-75.

DOI: 10.3844/ajeassp.2009.70.75

Abu-Lebdeh, T.M., G. Pérez-de León, S.A. Hamoush, R.D. Seals and V.E. Lamberti, 2016. Gas atomization of molten metal: Part II. applications. Am. J. Eng. Applied Sci., 9: 334-349. DOI: 10.3844/ajeassp.2016.334.349

Agarwala, S., 2016. A perspective on 3D bioprinting technology: Present and future. Am. J. Eng. Applied Sci., 9: 985-990. DOI: 10.3844/ajeassp.2016.985.990

Ahmed, M., R. Khan, M. Billah and S. Farhana, 2010. A novel navigation algorithm for hexagonal hexapod robot, Am. J. Eng. Applied Sci., 3: 320-327. DOI: 10.3844/ajeassp.2010.320.327

Ahmed, R., M. Khan, H. Haque and H. Rahman, 2016. An approach to develop a dynamic job shop scheduling by fuzzy rule-based system and comparative study with the traditional priority rules. Am. J. Eng. Applied Sci., 9: 202-212. DOI: 10.3844/ajeassp.2016.202.212

Akhesmeh, S., N. Pourmahmoud and H. Sedgi, 2008. Numerical study of the temperature separation in the ranque-hilsch vortex tube. Am. J. Eng. Applied Sci., 1: 181-187. DOI: 10.3844/ajeassp.2008.181.187
Al Qadi, A.N.S., M.B.A. Alhasanat and M. Haddad, 2016b. Effect of crumb rubber as coarse and fine aggregates on the properties of asphalt concrete. Am. J. Eng. Applied Sci., 9: 558-564. DOI: 10.3844/ajeassp.2016.558.564

AL Qadi, A.N.S., M.B.A. ALhasanat, A. AL Dahamsheh and S. AL Zaiydneen, 2016a. Using of box-benken method to predict the compressive strength of selfcompacting concrete containing wadi musa bentonite, Jordan. Am. J. Eng. Applied Sci., 9: 406-411.

DOI: 10.3844/ajeassp.2016.406.411

Al Smadi, T.A., 2011. Low cost smart sensor design. Am. J. Eng. Applied Sci., 4: 162-168.

DOI: 10.3844/ajeassp.2011.162.168

Al-Abbas, I.K., 2009. Reduced order models of a current source inverter induction motor drive. Am. J. Eng. Applied Sci., 2: 39-43. DOI: 10.3844/ajeassp.2009.39.43

Aleksic, S. and A. Lovric, 2011. Energy consumption and environmental implications of wired access networks. Am. J. Eng. Applied Sci., 4: 531-539. DOI: 10.3844/ajeassp.2011.531.539

Al-Hasan, M.I. and A.S. Al-Ghamdi, 2016. Energy balance for a diesel engine operates on a pure biodiesel, diesel fuel and biodiesel-diesel blends. Am. J. Eng. Applied Sci., 9: 458-465. DOI: 10.3844/ajeassp.2016.458.465

Alhasanat, M.B., A.N. Al Qadi, O.A. Al Khashman and A. Dahamsheh, 2016. Scanning electron microscopic evaluation of self-compacting concrete spalling at elevated temperatures. Am. J. Eng. Applied Sci., 9: 119-127.

DOI: 10.3844 /ajeassp.2016.119.127

Ali, G.A.M., O. Fouad and S.A. Makhlouf, 2016. Electrical properties of cobalt oxide/silica nanocomposites obtained by sol-gel technique. Am. J. Eng. Applied Sci., 9: 12-16. DOI: 10.3844/ajeassp.2016.12.16

Ali, K.S. and J.L. Shumaker, 2013. Hardware in the loop simulator for multi-agent unmanned aerial vehicles environment. Am. J. Eng. Applied Sci., 6: 172-177. DOI: 10.3844/ajeassp.2013.172.177

Al-Nasra, M., M. Daoudb and T.M. Abu-Lebdeh, 2015. The use of the super absorbent polymer as water blocker in concrete structures. Am. J. Eng. Applied Sci., 8: 659-665. DOI: 10.3844/ajeassp.2015.659.665

Alwetaishi, M.S., 2016. Impact of building function on thermal comfort: A review paper. Am. J. Eng. Applied Sci., 9: 928-945.

DOI: 10.3844/ajeassp.2016.928.945

Aly, W.M. and MS. Abuelnasr, 2010. Electronic design automation using object oriented electronics. Am. J. Eng. Applied Sci., 3: 121-127.

DOI: 10.3844/ajeassp.2010.121.127 
Amani, N., 2016. Design and implementation of optimum management system using cost evaluation and financial analysis for prevention of building failure. Am. J. Eng. Applied Sci., 9: 281-296. DOI: 10.3844/ajeassp.2016.281.296

Amer, S., S. Hamoush and T.M. Abu-Lebdeh, 2015. Experimental evaluation of the raking energy in damping system of steel stud partition walls. Am. J. Eng. Applied Sci., 8: 666-677.

DOI: 10.3844/ajeassp.2015.666.677

Anizan, S., K. Yusri, C.S. Leong, N. Amin, S. Zaidi and K. Sopian, 2011. Effects of the contact resistivity variations of the screen-printed silicon solar cell. Am. J. Eng. Applied Sci., 4: 328-331. DOI: 10.3844/ajeassp.2011.328.331

Antonescu, P. and F. Petrescu, 1985. An analytical method of synthesis of cam mechanism and flat stick. Proceedings of the 4th International Symposium on Theory and Practice of Mechanisms (TPM' 89), Bucharest.

Antonescu, P. and F. Petrescu, 1989. Contributions to kinetoplast dynamic analysis of distribution mechanisms. Bucharest.

Antonescu, P., F. Petrescu and D. Antonescu, 1997. Geometrical synthesis of the rotary cam and balance tappet mechanism. Bucharest, 3: 23-23.

Antonescu, P., F. Petrescu and O. Antonescu, 1994. Contributions to the synthesis of the rotating cam mechanism and the tip of the balancing tip. Brasov.

Antonescu, P., F. Petrescu and O. Antonescu, 2000a. Contributions to the synthesis of the rotary disccam profile. Proceedings of the 8th International Conference on the Theory of Machines and Mechanisms (TMM' 00), Liberec, Czech Republic, pp: 51-56.

Antonescu, P., F. Petrescu and O. Antonescu, $2000 \mathrm{~b}$. Synthesis of the rotary cam profile with balance follower. Proceedings of the 8th Symposium on Mechanisms and Mechanical Transmissions (MMT' 00), Timişoara, pp: 39-44.

Antonescu, P., F. Petrescu and O. Antonescu, 2001. Contributions to the synthesis of mechanisms with rotary disc-cam. Proceedings of the 8th IFToMM International Symposium on Theory of Machines and Mechanisms (TMM' 01), Bucharest, ROMANIA, pp: 31-36.

Antonescu, P., M. Oprean and F. Petrescu, 1985a. Contributions to the synthesis of oscillating cam mechanism and oscillating flat stick. Proceedings of the 4th International Symposium on Theory and Practice of Mechanisms (TPM' 85), Bucharest.

Antonescu, P., M. Oprean and F. Petrescu, 1985b. At the projection of the oscillate cams, there are mechanisms and distribution variables. Proceedings of the 5th Conference of Engines, Automobiles, Tractors and Agricultural Machines (TAM' 58), IMotors and Cars, Brasov.
Antonescu, P., M. Oprean and F. Petrescu, 1986. Projection of the profile of the rotating camshaft acting on the oscillating plate with disengagement. Proceedings of the 3rd National Computer-aided Design Symposium in the field of Mechanisms and Machine Parts (MMP' 86), Brasov.

Antonescu, P., M. Oprean and F. Petrescu, 1987. Dynamic analysis of the cam distribution mechanisms. Proceedings of the 7th National Symposium on Industrial Robots and Space Mechanisms (RSM' 87), Bucharest.

Antonescu, P., M. Oprean and F. Petrescu, 1988. Analytical synthesis of Kurz profile, rotating the flat cam. Mach, Build. Rev.

Ascione, F., N. Bianco, R.F. De Masi, F. de Rossi and C. De Stasio et al., 2016b. Energy audit of health care facilities: dynamic simulation of energy performances and energy-oriented refurbishment of system and equipment for microclimatic control. Am. J. Eng. Applied Sci., 9: 814-834. DOI: 10.3844 /ajeassp.2016.814.834

Augustine, A., R.D. Prakash, R. Xavier and M.C. Parassery, 2016. Review of signal processing techniques for detection of power quality events. Am. J. Eng. Applied Sci., 9: 364-370. DOI: 10.3844 /ajeassp.2016.364.370

Aversa, R., D. Parcesepe, R.V. Petrescu, G. Chen and F.I.T. Petrescu et al., 2016b. Glassy amorphous metal injection molded induced morphological defects. Am. J. Applied Sci., 13: 1476-1482. DOI: 10.3844/ajassp.2016.1476.1482

Aversa, R., D. Parcesepe, R.V.V. Petrescu, F. Berto and G. Chen et al., 2017d. Process ability of bulk metallic glasses. Am. J. Applied Sci., 14: 294-301. DOI: 10.3844/ajassp.2017.294.301

Aversa, R., E.M. Buzea, R.V. Petrescu, A. Apicella and M. Neacsa et al., 2016e. Present a mechatronic system having able to determine the concentration of carotenoids. Am. J. Eng. Applied Sci., 9: 11061111. DOI: 10.3844/ajeassp.2016.1106.1111

Aversa, R., F. Tamburrino, R.V. Petrescu, F.I.T. Petrescu and M. Artur et al., $2016 \mathrm{~d}$. Biomechanically inspired shape memory effect machines driven by muscle like acting NiTi alloys. Am. J. Applied Sci., 13: 1264-1271. DOI: 10.3844/ajassp.2016.1264.1271

Aversa, R., F.I.T. Petrescu, R.V. Petrescu and A. Apicella, 2016a. Biomimetic FEA bone modeling for customized hybrid biological prostheses development. Am. J. Applied Sci., 13: 1060-1067. DOI: 10.3844/ajassp.2016.1060.1067

Aversa, R., F.I.T. Petrescu, R.V. Petrescu and A. Apicella, 2016o. Flexible stem trabecular prostheses. Am. J. Eng. Applied Sci., 9: 1213-1221. DOI: 10.3844/ajeassp.2016.1213.122 
Aversa, R., R.V. Petrescu, A. Apicella and F.I.T. Petrescu, 2016i. Mitochondria are naturally micro robots - a review. Am. J. Eng. Applied Sci., 9: 991-1002. DOI: 10.3844/ajeassp.2016.991.1002

Aversa, R., R.V. Petrescu, A. Apicella and F.I.T. Petrescu, 2016j. We are addicted to vitamins $\mathrm{C}$ and E-A review. Am. J. Eng. Applied Sci., 9: 1003-1018. DOI: 10.3844/ajeassp.2016.1003.1018

Aversa, R., R.V. Petrescu, A. Apicella and F.I.T. Petrescu, 2016k. Physiologic human fluids and swelling behavior of hydrophilic biocompatible hybrid ceramo-polymeric materials. Am. J. Eng. Applied Sci., 9: 962-972.

DOI: 10.3844/ajeassp.2016.962.972

Aversa, R., R.V. Petrescu, A. Apicella and F.I.T. Petrescu, 20161. One can slow down the aging through antioxidants. Am. J. Eng. Applied Sci., 9: 1112-1126. DOI: 10.3844/ajeassp.2016.1112.1126

Aversa, R., R.V. Petrescu, A. Apicella and F.I.T. Petrescu, 2016m. About homeopathy or «Similia Similibus Curentur $\gg$. Am. J. Eng. Applied Sci., 9: 1164-1172. DOI: 10.3844/ajeassp.2016.1164.1172

Aversa, R., R.V. Petrescu, A. Apicella and F.I.T. Petrescu, 2016n. The basic elements of life's. Am. J. Eng. Applied Sci., 9: 1189-1197.

DOI: 10.3844/ajeassp.2016.1189.1197

Aversa, R., R.V. Petrescu, A. Apicella, F.I.T. Petrescu and J.K. Calautit et al., 2017c. Something about the $\mathrm{V}$ engines design. Am. J. Applied Sci., 14: 34-52. DOI: 10.3844/ajassp.2017.34.52

Aversa, R., R.V. Petrescu, B. Akash, R.B. Bucinell and J.M. Corchado et al., 2017b. Kinematics and forces to a new model forging manipulator. Am. J. Applied Sci., 14: 60-80. DOI: 10.3844/ajassp.2017.60.80

Aversa, R., R.V. Petrescu, F.I.T. Petrescu and A. Apicella, 2016c. Smart-factory: Optimization and process control of composite centrifuged pipes. Am. J. Applied Sci., 13: 1330-1341.

DOI: 10.3844/ajassp.2016.1330.1341

Aversa, R., R.V. Petrescu, F.I.T. Petrescu and A. Apicella, 2016h. Biomimetic and evolutionary design driven innovation in sustainable products development. Am. J. Eng. Applied Sci., 9: 1027-1036. DOI: 10.3844/ajeassp.2016.1027.1036

Aversa, R., R.V. Petrescu, R. Sorrentino, F.I.T. Petrescu and A. Apicella, 2016f. Hybrid ceramo-polymeric nanocomposite for biomimetic scaffolds design and preparation. Am. J. Eng. Applied Sci., 9: 1096-1105. DOI: 10.3844/ajeassp.2016.1096.1105

Aversa, R., R.V.V. Petrescu, A. Apicella and F.I.T. Petrescu, 2017a. Nano-diamond hybrid materials for structural biomedical application. Am. J. Biochem. Biotechnol., 13: 34-41.

DOI: $10.3844 /$ ajbbsp.2017.34.41
Aversa, R., R.V.V. Petrescu, B. Akash, R.B. Bucinell and J.M. Corchado et al., 2017e. Something about the balancing of thermal motors. Am. J. Eng. Applied Sci., 10: 200.217. DOI: 10.3844 /ajeassp.2017.200.217

Aversa, R., V. Perrotta, R.V. Petrescu, C. Misiano and F.I.T. Petrescu et al., 2016g. From structural colors to super-hydrophobicity and achromatic transparent protective coatings: Ion plating plasma assisted $\mathrm{TiO} 2$ and $\mathrm{SiO} 2$ nano-film deposition. Am. J. Eng. Applied Sci., 9: 1037-1045. DOI: 10.3844/ajeassp.2016.1037.1045

Babayemi, A.K., 2016. Thermodynamics, non-linear isotherms, statistical modeling and optimization of phosphorus adsorption from wastewater. Am. J. Eng. Applied Sci., 9: 1019-1026. DOI: 10.3844 /ajeassp.2016.1019.1026

Bakar, R.A., M.K. Mohammed and M.M. Rahman, 2009. Numerical study on the performance characteristics of hydrogen fueled port injection internal combustion engine. Am. J. Eng. Applied Sci., 2: 407-415. DOI: 10.3844/ajeassp.2009.407.415

Barone, G., A. Buonomano, C. Forzano and A. Palombo, 2016. WLHP systems in commercial buildings: A case study analysis based on a dynamic simulation approach. Am. J. Eng. Applied Sci., 9: 659-668. DOI: 10.3844/ajeassp.2016.659.668

Bedon, C., 2016. Review on the use of FRP composites for facades and building skins. Am. J. Eng. Applied Sci., 9: 713-723. DOI: 10.3844/ajeassp.2016.713.723

Bedon, C. and C. Amadio, 2016. A unified approach for the shear buckling design of structural glass walls with non-ideal restraints. Am. J. Eng. Applied Sci., 9: 64-78. DOI: 10.3844/ajeassp.2016.64.78

Bedon, C. and C. Louter, 2016. Finite-element numerical simulation of the bending performance of posttensioned structural glass beams with adhesively bonded CFRP tendons. Am. J. Eng. Applied Sci., 9: 680-691. DOI: 10.3844/ajeassp.2016.680.691

Bier, H. and S. Mostafavi, 2015. Structural optimization for materially informed design to robotic production processes. Am. J. Eng. Applied Sci., 8: 549-555. DOI: 10.3844/ajeassp.2015.549.555

Bolonkin, A., 2009a. Femtotechnology: Nuclear matter with fantastic properties. Am. J. Eng. Applied Sci., 2: 501-514. DOI: 10.3844/ajeassp.2009.501.514

Bolonkin, A., 2009b. Converting of matter to nuclear energy by AB-generator. Am. J. Eng. Applied Sci., 2: 683-693. DOI: 10.3844/ajeassp.2009.683.693

Boucetta, A., 2008. Vector control of a variable reluctance machine stator and rotor discs imbricates. Am. J. Eng. Applied Sci., 1: 260-265. DOI: 10.3844 /ajeassp.2008.260.265

Bourahla, N. and A. Blakeborough, 2015. Similitude distortion compensation for a small scale model of a knee braced steel frame. Am. J. Eng. Applied Sci., 8: 481-488. DOI: 10.3844/ajeassp.2015.481.488 
Bucinell, R.B., 2016. Stochastic model for variable amplitude fatigue induced delamination growth in graphite/epoxy laminates. Am. J. Eng. Applied Sci., 9: 635-646. DOI: 10.3844/ajeassp.2016.635.646

Budak, S., Z. Xiao, B. Johnson, J. Cole and M. Drabo et al., 2016. Highly-efficient advanced thermoelectric devices from different multilayer thin films. Am. J. Eng. Applied Sci., 9: 356-363.

DOI: 10.3844/ajeassp.2016.356.363

Buonomano, A., F. Calise and M. Vicidomini, 2016a. A novel prototype of a small-scale solar power plant: Dynamic simulation and thermoeconomic analysis. Am. J. Eng. Applied Sci., 9: 770-788.

DOI: 10.3844/ajeassp.2016.770.788

Buonomano, A., F. Calise, M.D. D'accadia, R. Vanoli and M. Vicidomini, 2016b. Simulation and experimental analysis of a demonstrative solar heating and cooling plant installed in Naples (Italy), Am. J. Eng. Applied Sci., 9: 798-813. DOI: 10.3844/ajeassp.2016.798.813

Calise, F., M.D. Dâ' Accadia, L. Libertini, E. Quiriti and M. Vicidomini, 2016b. Dynamic simulation and optimum operation strategy of a trigeneration system serving a hospital. Am. J. Eng. Applied Sci., 9: 854-867. DOI: 10.3844/ajeassp.2016.854.867

Campo, T., M. Cotto, F. Marquez, E. Elizalde and C. Morant, 2016. Graphene synthesis by plasmaenhanced CVD growth with ethanol. Am. J. Eng. Applied Sci., 9: 574-583.

DOI: 10.3844/ajeassp.2016.574.583

Cao, W., H. Ding, Z. Bin and C. Ziming, 2013. New structural representation and digital-analysis platform for symmetrical parallel mechanisms. Int. J. Adv. Robotic Syst.

Cardu, M., P. Oreste and T. Cicala, 2009. Analysis of the tunnel boring machine advancement on the bolognaflorence railway link. Am. J. Eng. Applied Sci., 2: 416-420. DOI: 10.3844/ajeassp.2009.416.420

Casadei, D. 2015. Bayesian statistical inference for number counting experiments. Am. J. Eng. Applied Sci., 8: 730-735. DOI: 10.3844/ajeassp.2015.730.735

Chang, S.P., M.C. Chen and J.D. Lin, 2015. Study of heat-treated steel and related applications. Am. J. Eng. Applied Sci., 8: 611-619.

DOI: 10.3844/ajeassp.2015.611.619

Chen, G. and L. Xu, 2016. A general strategy to enhance upconversion luminescence in rare-earth-ion-doped oxide nanocrystals. Am. J. Eng. Applied Sci., 9: 79-83. DOI: 10.3844/ajeassp.2016.79.83

Chiozzi, A., G. Milani, N. Grillanda and A. Tralli, 2016. An adaptive procedure for the limit analysis of FRP reinforced masonry vaults and applications. Am. J. Eng. Applied Sci., 9: 735-745.

DOI: 10.3844/ajeassp.2016.735.745
Chisari, C. and C. Bedon, 2016. Multi-objective optimization of FRP jackets for improving the seismic response of reinforced concrete frames. Am. J. Eng. Applied Sci., 9: 669-679. DOI: 10.3844/ajeassp.2016.669.679

Comanescu, A., 2010. Bazele Modelarii Mecanismelor. 1st Edn., Politeh, Press, Bucureşti.

Darabi, A., S.A. Soleamani and A. Hassannia, 2008. Fuzzy based digital automatic voltage regulator of a synchronous generator with unbalanced loads. Am. J. Eng. Applied Sci., 1: 280-286. DOI: 10.3844/ajeassp.2008.280.286

Daud, H., N. Yahya, A.A. Aziz and M.F. Jusoh, 2008. Development of wireless electric concept powering electrical appliances. Am. J. Eng. Applied Sci., 1: 12-15. DOI: 10.3844/ajeassp.2008.12.15

Demetriou, D., N. Nikitas and K.D. Tsavdaridis, 2015. Semi active tuned mass dampers of buildings: A simple control option. Am. J. Eng. Applied Sci., 8: 620-632. DOI: 10.3844/ajeassp.2015.620.632

Dixit, S. and S. Pal, 2015. Synthesis and characterization of ink (carbon)-perovskite/polyaniline ternary composite electrode for sodium chloride separation. Am. J. Eng. Applied Sci., 8: 527-537. DOI: 10.3844/ajeassp.2015.527.537

Djalel, D., M. Mourad and H. Labar, 2013. New approach of electromagnetic fields of the lightning discharge. Am. J. Eng. Applied Sci., 6: 369-383. DOI: 10.3844 /ajeassp.2013.369.383

Dong, H., N. Giakoumidis, N. Figueroa and N. Mavridis, 2013. Approaching behaviour monitor and vibration indication in developing a General Moving Object Alarm System (GMOAS). Int. J. Adv. Robotic Syst.

Santos, D.F.A. and C. Bedon, 2016. Preliminary experimental and finite-element numerical assessment of the structural performance of smareinforced GFRP systems. Am. J. Eng. Applied Sci., 9: 692-701. DOI: 10.3844/ajeassp.2016.692.701

Ebrahim, N.A., S. Ahmed, S.H.A. Rashid and Z. Taha, 2012. Technology use in the virtual $R$ and D teams. Am. J. Eng. Applied Sci., 5: 9-14. DOI: 10.3844/ajeassp.2012.9.14

El-Labban, H.F., M. Abdelaziz and E.R.I. Mahmoud, 2013. Modification of carbon steel by laser surface melting: Part I: Effect of laser beam travelling speed on microstructural features and surface hardness. Am. J. Eng. Applied Sci., 6: 352-359. DOI: 10.3844/ajeassp.2013.352.359

Elliott, A., S. AlSalihi, A.L. Merriman and M.M. Basti, 2016. Infiltration of nanoparticles into porous binder jet printed parts. Am. J. Eng. Applied Sci., 9: 128-133. DOI: 10.3844/ajeassp.2016.128.133

Elmeddahi, Y., H. Mahmoudi, A. Issaadi, M.F.A. Goosen and R. Ragab, 2016. Evaluating the effects of climate change and variability on water resources: A case study of the cheliff basin in algeria. Am. J. Eng. Applied Sci., 9: 835-845. DOI: 10.3844 /ajeassp.2016.835.845 
El-Tous, Y., 2008. Pitch angle control of variable speed wind turbine. Am. J. Eng. Applied Sci., 1: 118-120. DOI: 10.3844/ajeassp.2008.118.120

Faizal, A., S. Mulyono, R. Yendra and A. Fudholi, 2016. Design Maximum Power Point Tracking (MPPT) on photovoltaic panels using fuzzy logic method. Am. J. Eng. Applied Sci., 9: 789-797. DOI: 10.3844 /ajeassp.2016.789.797

Farahani, A.S., N.M. Adam and M.K.A. Ariffin, 2010. Simulation of airflow and aerodynamic forces acting on a rotating turbine ventilator. Am. J. Eng. Applied Sci., 3: 159-170. DOI: 10.3844/ajeassp.2010.159.170

Farokhi, E. and M. Gordini, 2015. Investigating the parameters influencing the behavior of knee braced steel structures. Am. J. Eng. Applied Sci., 8: 567-574. DOI: 10.3844/ajeassp.2015.567.574

Fathallah, A.Z.M. and R.A. Bakar, 2009. Prediction studies for the performance of a single cylinder high speed spark ignition linier engine with spring mechanism as return cycle. Am. J. Eng. Applied Sci., 2: 713-720. DOI: 10.3844/ajeassp.2009.713.720

Fen, Y.W., W.M.M. Yunus, M.M. Moksin, Z.A. Talib and N.A. Yusof, 2011. Optical properties of crosslinked chitosan thin film with glutaraldehyde using surface plasmon resonance technique. Am. J. Eng. Applied Sci., 4: 61-65. DOI: 10.3844/ajeassp.2011.61.65

Feraga, C.E., A. Moussaoui, A. Bouldjedri and A. Yousfi, 2009. Robust position controller for a permanent magnet synchronous actuator. Am. J. Eng. Applied Sci., 2: 388-392.

DOI: $10.3844 /$ ajeassp.2009.388.392

Franklin, D.J., 1930. Ingenious Mechanisms for Designers and Inventors. 1st Edn., Industrial Press Publisher.

Fu, Y.F., Gong, J., H. Huang, Y.J. Liu and D. Zhu et al., 2015. Parameters optimization of adaptive cashew shelling cutter based on BP neural network and genetic algorithm. Am. J. Eng. Applied Sci., 8: 648658. DOI: 10.3844/ajeassp.2015.648.658

Ge, L. and X. Xu, 2015. A scheme design of cloud+end technology in demand side management. Am. J. Eng. Applied Sci., 8: 736-747.

DOI: 10.3844/ajeassp.2015.736.747

Gupta, P., A. Gupta and A. Asati, 2015. Ultra low power MUX based compressors for wallace and dadda multipliers in sub-threshold regime. Am. J. Eng. Applied Sci., 8: 702-716.

DOI: 10.3844 /ajeassp.2015.702.716

Gusti, A.P. and Semin, 2016. The effect of vessel speed on fuel consumption and exhaust gas emissions. Am. J. Eng. Applied Sci., 9: 1046-1053.

DOI: 10.3844/ajeassp.2016.1046.1053

Hasan, S. and M.H. El-Naas, 2016. Optimization of a combined approach for the treatment of carbide slurry and capture of CO2. Am. J. Eng. Applied Sci., 9: 449-457. DOI: 10.3844/ajeassp.2016.449.457
Hassan, M., H. Mahjoub and M. Obed, 2012. Voicebased control of a DC servo motor. Am. J. Eng. Applied Sci., 5: 89-92.

DOI: 10.3844/ajeassp.2012.89.92

He, B., Z. Wang, Q. Li, H. Xie and R. Shen, 2013. An analytic method for the kinematics and dynamics of a multiple-backbone continuum robot. IJARS.

Helmy, A.K. and G.h.S. El-Taweel, 2010. Neural network change detection model for satellite images using textural and spectral characteristics. Am. J. Eng. Applied Sci., 3: 604-610.

DOI: 10.3844/ajeassp.2010.604.610

Hirun, W., 2016. Evaluation of interregional freight generation modelling methods by using nationwide commodity flow survey data. Am. J. Eng. Applied Sci., 9: 625-634. DOI: 10.3844/ajeassp.2016.625.634

Ho, C.Y.F., B.W.K. Ling, S.G. Blasi, Z.W. Chi and W.C. Siu, 2011. Single step optimal block matched motion estimation with motion vectors having arbitrary pixel precisions. Am. J. Eng. Applied Sci., 4: 448-460. DOI: 10.3844/ajeassp.2011.448.460

Huang, B., S.H. Masood, M. Nikzad, P.R. Venugopal and A. Arivazhagan, 2016. Dynamic mechanical properties of fused deposition modelling processed polyphenylsulfone material. Am. J. Eng. Applied Sci., 9: 1-11. DOI: 10.3844/ajeassp.2016.1.11

Idarwazeh, S., 2011. Inverse discrete fourier transformdiscrete fourier transform techniques for generating and receiving spectrally efficient frequency division multiplexing signals. Am. J. Eng. Applied Sci., 4: 598-606. DOI: 10.3844/ajeassp.2011.598.606

Iqbal, M., 2016. An Overview of Energy Loss Reduction (ELR) software used in pakistan by WAPDA for calculating transformer overloading, line losses and energy losses. Am. J. Eng. Applied Sci., 9: 442-448. DOI: 10.3844/ajeassp.2016.442.448

Jaber, A.A. and R. Bicker, 2016. Industrial robot fault detection based on statistical control chart. Am. J. Eng. Applied Sci., 9: 251-263. DOI: 10.3844/ajeassp.2016.251.263

Jafari, N., A. Alsadoon, C.P. Withana, A. Beg and A. Elchouemi, 2016. Designing a comprehensive security framework for smartphones and mobile devices. Am. J. Eng. Applied Sci., 9: 724-734. DOI: 10.3844 /ajeassp.2016.724.734

Jalil, M.I.A. and J. Sampe, 2013. Experimental investigation of thermoelectric generator modules with different technique of cooling system. Am. J. Eng. Applied Sci., 6: 1-7. DOI: 10.3844/ajeassp.2013.1.7

Jaoude, A.A. and K. El-Tawil, 2013. Analytic and nonlinear prognostic for vehicle suspension systems. Am. J. Eng. Applied Sci., 6: 42-56. DOI: 10.3844 /ajeassp.2013.42.56

Jarahi, H. and S. Seifilaleh, 2016. Rock fall hazard zonation in haraz highway. Am. J. Eng. Applied Sci., 9: 371-379. DOI: 10.3844/ajeassp.2016.371.379 
Jarahi, H., 2016. Probabilistic seismic hazard deaggregation for karaj city (Iran). Am. J. Eng. Applied Sci., 9: 520-529.

DOI: 10.3844 /ajeassp.2016.520.529

Jauhari, K., A. Widodo and I. Haryanto, 2016. Identification of a machine tool spindle critical frequency through modal and imbalance response analysis. Am. J. Eng. Applied Sci., 9: 213-221. DOI: 10.3844/ajeassp.2016.213.221

Jiang, J., Q. Chen and S. Nimbalkar, 2016. Field data based method for predicting long-term settlements. Am. J. Eng. Applied Sci., 9: 466-476. DOI: 10.3844/ajeassp.2016.466.476

Kaewnai, S. and S. Wongwises, 2011. Improvement of the runner design of francis turbine using computational fluid dynamics. Am. J. Eng. Applied Sci., 4: 540-547.

DOI: 10.3844 /ajeassp.2011.540.547

Kamble, V.G. and N.L. Kumar, 2016. Fabrication and tensile property analysis of polymer matrix composites of graphite and silicon carbide as fillers. Am. J. Eng. Applied Sci., 9: 17-30. DOI: 10.3844 /ajeassp.2016.17.30

Kazakov, V.V., V.I. Yusupov, V.N. Bagratashvili, A.I. Pavlikov and V.A. Kamensky, 2016. Control of bubble formation at the optical fiber tip by analyzing ultrasound acoustic waves, Am. J. Eng. Applied Sci., 9: 921-927. DOI: 10.3844/ajeassp.2016.921.927

Kechiche, O.B.H.B., H.B.A. Sethom, H. Sammoud and I.S. Belkhodja, 2011. Optimized high-frequency signal injection based permanent magnet synchronous motor rotor position estimation applied to washing machines. Am. J. Eng. Applied Sci., 4: 390-399. DOI: 10.3844/ajeassp.2011.390.399

Khalifa, A.H.N., AH. Jabbar and J.A. Muhsin, 2015. Effect of exhaust gas temperature on the performance of automobile adsorption airconditioner. Am. J. Eng. Applied Sci., 8: 575-581. DOI: 10.3844/ajeassp.2015.575.581

Khalil, R., 2015. Credibility of 3D volume computation using GIS for pit excavation and roadway constructions. Am. J. Eng. Applied Sci., 8: 434-442. DOI: 10.3844/ajeassp.2015.434.442

Kuli, I., T.M. Abu-Lebdeh, E.H. Fini and S.A. Hamoush, 2016. The use of nano-silica for improving mechanical properties of hardened cement paste. Am. J. Eng. Applied Sci., 9: 146-154. DOI: 10.3844/ajeassp.2016.146.154

Kumar, N.D., R.D. Ravali and P.R. Srirekha, 2015. Design and realization of pre-amplifier and filters for on-board radar system. Am. J. Eng. Applied Sci., 8: 689-701. DOI: 10.3844/ajeassp.2015.689.701

Kunanoppadon, J., 2010. Thermal efficiency of a combined turbocharger set with gasoline engine. Am. J. Eng. Applied Sci., 3: 342-349.

DOI: 10.3844 /ajeassp.2010.342.349
Kwon, S., Y. Tani, H. Okubo and T. Shimomura, 2010. Fixed-star tracking attitude control of spacecraft using single-gimbal control moment gyros. Am. J. Eng. Applied Sci., 3: 49-55. DOI: 10.3844 /ajeassp.2010.49.55

Lamarre, A., E.H. Fini and T.M. Abu-Lebdeh, 2016. Investigating effects of water conditioning on the adhesion properties of crack sealant. Am. J. Eng. Applied Sci., 9: 178-186.

DOI: 10.3844/ajeassp.2016.178.186

Lee, B.J., 2013. Geometrical derivation of differential kinematics to calibrate model parameters of flexible manipulator. Int. J. Adv. Robotic Syst.

Li, R., B. Zhang, S. Xiu, H. Wang and L. Wang et al., 2015. Characterization of solid residues obtained from supercritical ethanol liquefaction of swine manure. Am. J. Eng. Applied Sci., 8: 465-470. DOI: 10.3844 /ajeassp.2015.465.470

Lin, W., B. Li, X. Yang and D. Zhang, 2013. Modelling and control of inverse dynamics for a 5-DOF parallel kinematic polishing machine. Int. J. Adv. Robotic Syst.

Liu, H., W. Zhou, X. Lai and S. Zhu, 2013. An efficient inverse kinematic algorithm for a PUMA560structured robot manipulator. IJARS.

Lubis, Z., A.N. Abdalla, Mortaza and R. Ghon, 2009. Mathematical modeling of the three phase induction motor couple to DC motor in hybrid electric vehicle. Am. J. Eng. Applied Sci., 2: 708-712. DOI: 10.3844 /ajeassp.2009.708.712

Madani, D.A. and A. Dababneh, 2016. Rapid entire body assessment: A literature review. Am. J. Eng. Applied Sci., 9: 107-118. DOI: 10.3844/ajeassp.2016.107.118

Malomar, G.E.B., A. Gueye, C. Mbow, V.B. Traore and A.C. Beye, 2016. Numerical study of natural convection in a square porous cavity thermally modulated on both side walls. Am. J. Eng. Applied Sci., 9: 591-598.

DOI: 10.3844/ajeassp.2016.591.598

Mansour, M.A.A., 2016. Developing an anthropometric database for saudi students and comparing saudi dimensions relative to turkish and iranian peoples. Am. J. Eng. Applied Sci., 9: 547-557. DOI: 10.3844/ajeassp.2016.547.557

Maraveas, C., Z.C. Fasoulakis and K.D. Tsavdaridis, 2015. A review of human induced vibrations on footbridges. Am. J. Eng. Applied Sci., 8: 422-433. DOI: 10.3844/ajeassp.2015.422.433

Marghany, M. and M. Hashim, 2009. Robust of doppler centroid for mapping sea surface current by using radar satellite data. Am. J. Eng. Applied Sci., 2: 781-788. DOI: 10.3844/ajeassp.2009.781.788

Martins, F.R., A.R. Gonçalves and E.B. Pereira, 2016. Observational study of wind shear in northeastern Brazil. Am. J. Eng. Applied Sci., 9: 484-504. DOI: 10.3844/ajeassp.2016.484.504 
Marzuki, M.A.l.B., M.H. Abd Halim and A.R.N. Mohamed, 2015. Determination of natural frequencies through modal and harmonic analysis of space frame race car chassis based on ANSYS. Am. J. Eng. Applied Sci., 8: 538-548.

DOI: 10.3844 /ajeassp.2015.538.548

Mavukkandy, M.O., S. Chakraborty, T. Abbasi and S.A. Abbasi, 2016. A clean-green synthesis of platinum nanoparticles utilizing a pernicious weed Lantana (Lantana Camara). Am. J. Eng. Applied Sci., 9: 84-90. DOI: 10.3844/ajeassp.2016.84.90

Minghini, F., N. Tullini and F. Ascione, 2016. Updating italian design guide CNR DT-205/2007 in view of recent research findings: Requirements for pultruded FRP profiles. Am. J. Eng. Applied Sci., 9: 702-712. DOI: 10.3844/ajeassp.2016.702.712

Ismail, M.I.S., Y. Okamoto, A. Okada and Y. Uno, 2011. Experimental investigation on micro-welding of thin stainless steel sheet by fiber laser. Am. J. Eng. Applied Sci., 4: 314-320. DOI: 10.3844/ajeassp.2011.314.320

Moezi, N., D. Dideban and A. Ketabi, 2008. A novel integrated SET based inverter for nano power electronic applications. Am. J. Eng. Applied Sci., 1: 219-222. DOI: 10.3844/ajeassp.2008.219.222

Mohamed, M.A., A.Y. Tuama, M. Makhtar, M.K. Awang and M. Mamat, 2016. The effect of RSA exponential key growth on the multi-core computational resource. Am. J. Eng. Applied Sci., 9: 1054-1061. DOI: 10.3844/ajeassp.2016.1054.1061

Mohan, K.S.R., P. Jayabalan and A. Rajaraman, 2012. Properties of fly ash based coconut fiber composite. Am. J. Eng. Applied Sci., 5: 29-34.

DOI: 10.3844/ajeassp.2012.29.34

Mohseni, E. and K.D. Tsavdaridis, 2016. Effect of nanoalumina on pore structure and durability of class f fly ash self-compacting mortar. Am. J. Eng. Applied Sci., 9: 323-333. DOI: 10.3844/ajeassp.2016.323.333

Momani, M.A., T.A. Al Smadi, F.M. Al Taweel and K.A. Ghaidan, 2011. GPS ionospheric total electron content and scintillation measurements during the October 2003 magnetic storm. Am. J. Eng. Applied Sci., 4: 301-306. DOI: 10.3844/ajeassp.2011.301.306

Momta, P.S., J.O. Omoboh and M.I. Odigi, 2015. Sedimentology and depositional environment of D2 sand in part of greater ughelli depobelt. Onshore Niger Delta, Nigeria. Am. J. Eng. Applied Sci., 8: 556-566. DOI: 10.3844/ajeassp.2015.556.566

Mondal, R., S. Sahoo and C.S. Rout, 2016. Mixed nickel cobalt manganese oxide nanorods for supercapacitor application. Am. J. Eng. Applied Sci., 9: 540-546. DOI: 10.3844/ajeassp.2016.540.546

Montgomery, J., T.M. Abu-Lebdeh, S.A. Hamoush and M. Picornell, 2016. Effect of nano-silica on the compressive strength of harden cement paste at different stages of hydration. Am. J. Eng. Applied Sci., 9: 166-177. DOI: 10.3844/ajeassp.2016.166.177
Moretti, M.L., 2015. Seismic design of masonry and reinforced concrete infilled frames: A comprehensive overview. Am. J. Eng. Applied Sci., 8: 748-766. DOI: 10.3844/ajeassp.2015.748.766

Morse, A., M.M. Mansfield, R.M. Alley, H.A. Kerr and R.B. Bucinell, 2016b. Traction enhancing products affect maximum torque at the shoe-floor interface: A potential increased risk of ACL injury. Am. J. Eng. Applied Sci., 9: 889-893.

DOI: 10.3844 ajeassp.2016.889.893

Moubarek, T. and A. Gharsallah, 2016. A six-port reflectometer calibration using wilkinson power divider. Am. J. Eng. Applied Sci., 9: 274-280.

DOI: 10.3844/ajeassp.2016.274.280

Nabilou, A., 2016a. Effect of parameters of selection and replacement drilling bits based on geomechanical factors: (case study: Gas and oil reservoir in the southwest of Iran). Am. J. Eng. Applied Sci., 9: 380-395.

DOI: 10.3844 /ajeassp.2016.380.395

Nabilou, A., 2016b. Study of the parameters of Steam Assisted Gravity Drainage (SAGD) method for enhanced oil recovery in a heavy oil fractured carbonate reservoir. Am. J. Eng. Applied Sci., 9: 647-658. DOI: 10.3844/ajeassp.2016.647.658

Nachiengtai, T., W. Chim-Oye, S. Teachavorasinskun and W. Sa-Ngiamvibool, 2008. Identification of shear band using elastic shear wave propagation. Am. J. Eng. Applied Sci., 1: 188-191.

DOI: 10.3844 /ajeassp.2008.188.191

Nahas, R. and S.P. Kozaitis, 2014. Metric for the fusion of synthetic and real imagery from multimodal sensors. Am. J. Eng. Applied Sci., 7: 355-362. DOI: 10.3844/ajeassp.2014.355.362

Nandhakumar, S., V. Selladurai and S. Sekar, 2009. Numerical investigation of an industrial robot arm control problem using haar wavelet series. Am. J. Eng. Applied Sci., 2: 584-589.

DOI: 10.3844/ajeassp.2009.584.589

Ng, K.C., M.Z. Yusoff, K. Munisamy, H. Hasini and N.H. Shuaib, 2008. Time-marching method for computations of high-speed compressible flow on structured and unstructured grid. Am. J. Eng. Applied Sci., 1: 89-94. DOI: 10.3844/ajeassp.2008.89.94

Obaiys, S.J., Z. Abbas, N.M.A. Nik Long, A. F. Ahmad and A. Ahmedov et al., 2016. On the general solution of first-kind hypersingular integral equations. Am. J. Eng. Applied Sci., 9: 195-201. DOI: 10.3844/ajeassp.2016.195.201

Odeh, S., R. Faqeh, L. Abu Eid and N. Shamasneh, 2009. Vision-based obstacle avoidance of mobile robot using quantized spatial model. Am. J. Eng. Applied Sci., 2: 611-619.

DOI: 10.3844/ajeassp.2009.611.619 
Ong, A.T., A. Mustapha, Z.B. Ibrahim, S. Ramli and B.C. Eong, 2015. Real-time automatic inspection system for the classification of PCB flux defects. Am. J. Eng. Applied Sci., 8: 504-518. DOI: 10.3844/ajeassp.2015.504.518

Opafunso, Z.O., I.I. Ozigis and I.A. Adetunde, 2009. Pneumatic and hydraulic systems in coal fluidized bed combustor. Am. J. Eng. Applied Sci., 2: 88-95. DOI: 10.3844/ajeassp.2009.88.95

Orlando, N. and E. Benvenuti, 2016. Advanced XFEM simulation of pull-out and debonding of steel bars and FRP-reinforcements in concrete beams. Am. J. Eng. Applied Sci., 9: 746-754. DOI: 10.3844/ajeassp.2016.746.754

Padula, F. and V. Perdereau, 2013. An on-line path planner for industrial manipulators. Int. J. Adv. Robotic Syst.

Perumaal, S. and N. Jawahar, 2013. Automated trajectory planner of industrial robot for pick-andplace task. IJARS.

Pannirselvam, N., P.N. Raghunath and K. Suguna, 2008. Neural network for performance of glass fibre reinforced polymer plated rc beams. Am. J. Eng. Applied Sci., 1: 82-88.

DOI: 10.3844/ajeassp.2008.82.88

Pattanasethanon, S., 2010. The solar tracking system by using digital solar position sensor. Am. J. Eng. Applied Sci., 3: 678-682. DOI: $10.3844 /$ ajeassp.2010.678.682

Pérez-de León, G., V.E. Lamberti, R.D. Seals, T.M. Abu-Lebdeh and S.A. Hamoush, 2016. Gas atomization of molten metal: Part I. numerical modeling conception. Am. J. Eng. Applied Sci., 9: 303-322. DOI: 10.3844/ajeassp.2016.303.322

Petrescu, F. and R. Petrescu, 1995a. Contributions to optimization of the polynomial motion laws of the stick from the internal combustion engine distribution mechanism. Bucharest, 1: 249-256.

Petrescu F.I.T. and R.V. Petrescu, 2015d. Presenting a railbound forging manipulator. Applied Mechan. Mat., 762: 219-224.

Petrescu, F. and R. Petrescu, 1995b. Contributions to the synthesis of internal combustion engine distribution mechanisms. Bucharest, 1: 257-264.

Petrescu, F. and R. Petrescu, 1997a. Dynamics of cam mechanisms (exemplified on the classic distribution mechanism). Bucharest, 3: 353-358.

Petrescu, F. and R. Petrescu, 1997b. Contributions to the synthesis of the distribution mechanisms of internal combustion engines with a Cartesian coordinate method. Bucharest, 3: 359-364.

Petrescu, F. and R. Petrescu, 1997c. Contributions to maximizing polynomial laws for the active stroke of the distribution mechanism from internal combustion engines. Bucharest, 3: 365-370.
Petrescu, F. and R. Petrescu, 2000a. Synthesis of distribution mechanisms by the rectangular (Cartesian) coordinate method. Proceedings of the 8th National Conference on International Participation (CIP' 00), Craiova, Romania, pp: 297-302.

Petrescu, F. and R. Petrescu, 2000b. The design (synthesis) of cams using the polar coordinate method (triangle method). Proceedings of the 8th National Conference on International Participation (CIP' 00), Craiova, Romania, pp: 291-296.

Petrescu, F. and R. Petrescu, 2002a. Motion laws for cams. Proceedings of the International Computer Assisted Design, National Symposium with Participation (SNP' 02), Braşov, pp: 321-326.

Petrescu, F. and R. Petrescu, 2002b. Camshaft dynamics elements. Proceedings of the International Computer Assisted Design, National Participation Symposium (SNP' 02), Braşov, pp: 327-332.

Petrescu, F. and R. Petrescu, 2003. Some elements regarding the improvement of the engine design. Proceedings of the National Symposium, Descriptive Geometry, Technical Graphics and Design (GTD' 03), Braşov, pp: 353-358.

Petrescu, F. and R. Petrescu, 2005a. The cam design for a better efficiency. Proceedings of the International Conference on Engineering Graphics and Design (EGD' 05), Bucharest, pp: 245-248.

Petrescu, F. and R. Petrescu, 2005b. Contributions at the dynamics of cams. Proceedings of the 9th IFToMM International Symposium on Theory of Machines and Mechanisms (TMM' 05), Bucharest, Romania, pp: 123-128.

Petrescu, F. and R. Petrescu, 2005c. Determining the dynamic efficiency of cams. Proceedings of the 9th IFToMM International Symposium on Theory of Machines and Mechanisms (TMM' 05), Bucharest, Romania, pp: 129-134.

Petrescu, F. and R. Petrescu, 2005d. An original internal combustion engine. Proceedings of the 9th IFToMM International Symposium on Theory of Machines and Mechanisms (TMM' 05), Bucharest, Romania, pp: $135-140$.

Petrescu, F. and R. Petrescu, 2005e. Determining the mechanical efficiency of Otto engine's mechanism. Proceedings of the 9th IFToMM International Symposium on Theory of Machines and Mechanisms (TMM' 05), Bucharest, Romania, pp: 141-146.

Petrescu, F.I. and R.V. Petrescu, 2011a. Mechanical Systems, Serial and Parallel (Romanian). 1st Edn., LULU Publisher, London, UK.

Petrescu, F.I. and R.V. Petrescu, 2012a. Kinematics of the planar quadrilateral mechanism. ENGEVISTA, 14: 345-348.

Petrescu, F.I. and R.V. Petrescu, 2012b. MecatronicaSisteme Seriale si Paralele. 1st Edn., Create Space Publisher, USA. 
Petrescu, F.I. and R.V. Petrescu, 2013a. Cinematics of the 3R dyad. ENGEVISTA, 15: 118-124.

Petrescu, F.I. and R.V. Petrescu, 2016a. Parallel moving mechanical systems kinematics. ENGEVISTA, 18: 455-491.

Petrescu, F.I. and R.V. Petrescu, 2016b. Direct and inverse kinematics to the anthropomorphic robots. ENGEVISTA, 18: 109-124.

Petrescu, F.I. and R.V. Petrescu, 2016c. Dynamic cinematic to a structure 2R. Revista Geintec-Gestao Inovacao E Tecnol., 6: 3143-3154.

Petrescu, F.I., B. Grecu, A. Comanescu and R.V. Petrescu, 2009. Some mechanical design elements. Proceeding of the International Conference on Computational Mechanics and Virtual Engineering (MVE' 09), Braşov, pp: 520-525.

Petrescu, F.I.T. and R.V. Petrescu, 2013b. Forces and efficiency of cams. Int. Rev. Mechanical Eng. J., 3: 507-511.

Petrescu, F.I.T. and R.V. Petrescu, 2013c. Cams with high efficiency. Int. Rev. Mechanical Eng. J., 4: 599-606.

Petrescu, F.I.T. and R.V. Petrescu, 2013d. An algorithm for setting the dynamic parameters of the classic distribution mechanism. Int. Rev. Modell. Simulat. J., 5: 1637-1641.

Petrescu, F.I.T. and R.V. Petrescu, 2013e. Dynamic synthesis of the rotary cam and translated tappet with roll. Int. Re. Modell. Simulat. J., 2: 600-607.

Petrescu, F.I.T. and R.V. Petrescu, 2014a. Parallel moving mechanical systems. Indepen. J. Manag. Produc., 3: 564-580.

Petrescu, F.I.T. and R.V. Petrescu, 2014c. Highefficiency gears synthesis by avoid the interferences. Indepen. J. Manag. Produc., 2: 275-298.

Petrescu, F.I.T. and R.V. Petrescu, 2014d. Gear design. J. ENGEVISTA, 4: 313-328.

Petrescu, F.I.T. and R.V. Petrescu, 2014e. Kinetostatic of the $3 \mathrm{R}$ dyad (or $2 \mathrm{R}$ module). J. ENGEVISTA, 3: 314-321.

Petrescu, F.I.T. and R.V. Petrescu, 2014f. Balancing otto engines. Int. Re. Mechani. J., 3: 473-480.

Petrescu, F.I.T. and R.V. Petrescu, 2014g. Machine equations to the classical distribution. Int. Rev. Mechan. Eng. J., 2: 309-316.

Petrescu, F.I.T. and R.V. Petrescu, 2014h. Forces of internal combustion heat engines. Int. Rev. Modell. Simulat. J., 1: 206-212.

Petrescu, F.I.T. and R.V. Petrescu, 2014i. Determination of the yield of internal combustion thermal engines. Int. Rev. Mechan. Eng. J., 1: 62-67.

Petrescu, F.I.T. and R.V. Petrescu, 2015a. Forces at the main mechanism of a railbound forging manipulator. Ind. J. Manag. Product., 6: 904-921.

Petrescu, F.I.T. and R.V. Petrescu, 2015b. Kinematics at the main mechanism of a railbound forging manipulator. Indepen. Manag. Product., 6: 711-729.
Petrescu, F.I.T. and R.V. Petrescu, 2015e. About the anthropomorphic robots. J. ENGEVISTA, 1: 1-15.

Petrescu, F.I.T. and R.V., Petrescu, 2014b. Cam gears dynamics in the classic distribution. Indepen. J. Manag. Produc., 1: 166-185.

Petrescu, F.I.T., 2011. Teoria Mecanismelor si a Masinilor: Curs Si Aplicatii. 1st Edn., CreateSpace Independent Publishing Platform. ISBN-10: 1468015826. pp: 432.

Petrescu, F.I.T., 2015a. Geometrical synthesis of the distribution mechanisms. Am. J. Eng. Applied Sci., 8: 63-81. DOI: 10.3844/ajeassp.2015.63.81

Petrescu, F.I.T., 2015b. Machine motion equations at the internal combustion heat engines. Am. J. Eng. Applied Sci., 8: 127-137. DOI: 10.3844/ajeassp.2015.127.137

Petrescu, F.I.T., A. Apicella, A. Raffaella, RV. Petrescu and J.K. Calautit et al., 2016. Something about the mechanical moment of inertia. Am. J. Applied Sci., 13: 1085-1090. DOI: 10.3844/ajassp.2016.1085.1090

Petrescu, F.I.T., R.V. Petrescu, 2015c. Machine motion equations. Indepen. J. Manag. Product., 6: 773-802.

Petrescu, FIT., Petrescu, RV., 2011b. Trenuri Planetare. 1st Edn., Createspace Independent Publisher, ISBN13: 978-1468030419, pp: 204.

Petrescu, FIT., Petrescu, RV., 2016d. An otto engine dynamic model. Indepen. J. Manag. Product., 7: 038-048.

Petrescu, R.V., R. Aversa, A. Apicella and F.I. Petrescu, 2016. Future medicine services robotics. Am. J. Eng. Applied Sci., 9: 1062-1087.

DOI: 10.3844 /ajeassp.2016.1062.1087

Petrescu, R.V., R. Aversa, A. Apicella and F.I.T. Petrescu, 2017k. Transportation engineering. Am. J. Eng. Applied Sci., 10: 685-702.

DOI: 10.3844 /ajeassp.2017.685.702

Petrescu, R.V., R. Aversa, A. Apicella and F.I.T. Petrescu, 2018c. Friendly environmental transport. Am. J. Eng. Applied Sci., 11: 154-165. DOI: 10.3844 /ajeassp.2018.154.165

Petrescu, R.V., R. Aversa, A. Apicella and F.I.T. Petrescu, 2018j. Romanian engineering "on the wings of the wind". J. Aircraft Spacecraft Technol., 2: 1-18. DOI: $10.3844 /$ jastsp.2018.1.18

Petrescu, R.V., R. Aversa, A. Apicella and F.I.T. Petrescu, 2018k. NASA data used to discover eighth planet circling distant star. J. Aircraft Spacecraft Technol., 2: 19-30. DOI: 10.3844/jastsp.2018.19.30

Petrescu, R.V., R. Aversa, A. Apicella and F.I.T. Petrescu, 20181. NASA has found the most distant black hole. J. Aircraft Spacecraft Technol., 2: 31-39. DOI: 10.3844 jastsp.2018.31.39

Petrescu, R.V., R. Aversa, A. Apicella and F.I.T. Petrescu, 2018m. Nasa selects concepts for a new mission to titan, the moon of saturn. J. Aircraft Spacecraft Technol., 2: 40-52.

DOI: $10.3844 /$ jastsp.2018.40.52 
Petrescu, R.V., R. Aversa, A. Apicella and F.I.T. Petrescu, 2018n. NASA sees first in 2018 the direct proof of ozone hole recovery. J. Aircraft Spacecraft Technol., 2: 53-64. DOI: 10.3844/jastsp.2018.53.64

Petrescu, R.V., R. Aversa, A. Apicella, M.M. Mirsayar and S. Kozaitis et al., 2018a. NASA started a propeller set on board voyager 1 after 37 years of break. Am. J. Eng. Applied Sci., 11: 66-77. DOI: 10.3844/ajeassp.2018.66.77

Petrescu, R.V., R. Aversa, A. Apicella, M.M. Mirsayar and S. Kozaitis et al., 2018b. There is life on mars? Am. J. Eng. Applied Sci., 11: 78-91. DOI: 10.3844 /ajeassp.2018.78.91

Petrescu, R.V., R. Aversa, B. Akash, B. Ronald and J. Corchado et al., 2017b. Velocities and accelerations at the 3R mechatronic systems. Am. J. Eng. Applied Sci., 10: 252-263. DOI: 10.3844/ajeassp.2017.252.263

Petrescu, R.V., R. Aversa, B. Akash, R. Bucinell and J. Corchado et al., 2017c. Anthropomorphic solid structures n-r kinematics. Am. J. Eng. Applied Sci., 10: 279-291. DOI: 10.3844/ajeassp.2017.279.291

Petrescu, R.V., R. Aversa, B. Akash, F. Berto and A. Apicella et al., 2017z. The modern flight. J. Aircraft Spacecraft Technol., 1: 224-233. DOI: 10.3844 /jastsp.2017.224.233

Petrescu, R.V., R. Aversa, B. Akash, F. Berto and A. Apicella et al., 2017aa. Sustainable energy for aerospace vessels. J. Aircraft Spacecraft Technol., 1: 234-240. DOI: 10.3844/jastsp.2017.234.240

Petrescu, R.V., R. Aversa, B. Akash, F. Berto and A. Apicella et al., 2017ab. Unmanned helicopters. J. Aircraft Spacecraft Technol., 1: 241-248. DOI: $10.3844 /$ jastsp.2017.241.248

Petrescu, R.V., R. Aversa, B. Akash, F. Berto and A. Apicella et al., 2017ac. Project HARP. J. Aircraft Spacecraft Technol., 1: 249-257.

DOI: $10.3844 /$ jastsp.2017.249.257

Petrescu, R.V., R. Aversa, B. Akash, F. Berto and A. Apicella et al., 2017ad. Presentation of Romanian engineers who contributed to the development of global aeronautics-part I. J. Aircraft Spacecraft Technol., 1: 258-271.

DOI: $10.3844 /$ jastsp.2017.258.271

Petrescu, R.V., R. Aversa, B. Akash, F. Berto and A. Apicella et al., 2017ae. A first-class ticket to the planet mars, please. J. Aircraft Spacecraft Technol., 1: 272-281. DOI: 10.3844/jastsp.2017.272.281

Petrescu, R.V., R. Aversa, B. Akash, J. Corchado and F. Berto et al., 2017q. Our universe. J. Aircraft Spacecraft Technol., 1: 69-79. DOI: $10.3844 /$ jastsp.2017.69.79

Petrescu, R.V., R. Aversa, B. Akash, J. Corchado and F. Berto et al., 2017r. What is a UFO? J. Aircraft Spacecraft Technol., 1: 80-90.

DOI: 10.3844 jastsp.2017.80.90
Petrescu, R.V., R. Aversa, B. Akash, J. Corchado and F. Berto et al., 2017s. About bell helicopter FCX-001 concept aircraft-a short review. J. Aircraft Spacecraft Technol., 1: 91-96. DOI: 10.3844 jastsp.2017.91.96

Petrescu, R.V., R. Aversa, B. Akash, J. Corchado and F. Berto et al., 2017t. Home at airbus. J. Aircraft Spacecraft Technol., 1: 97-118. DOI: 10.3844 /jastsp.2017.97.118

Petrescu, R.V., R. Aversa, B. Akash, J. Corchado and F. Berto et al., 2017u. Airlander. J. Aircraft Spacecraft Technol., 1: 119-148. DOI: 10.3844 /jastsp.2017.119.148

Petrescu, R.V., R. Aversa, B. Akash, J. Corchado and F. Berto et al., 2017v. When boeing is dreaming-a review. J. Aircraft Spacecraft Technol., 1: 149-161. DOI: 10.3844 /jastsp.2017.149.161

Petrescu, R.V., R. Aversa, B. Akash, J. Corchado and F. Berto et al., 2017w. About Northrop Grumman. J. Aircraft Spacecraft Technol., 1: 162-185. DOI: 10.3844 /jastsp.2017.162.185

Petrescu, R.V., R. Aversa, B. Akash, J. Corchado and F. Berto et al., 2017x. Some special aircraft. J. Aircraft Spacecraft Technol., 1: 186-203. DOI: $10.3844 /$ jastsp.2017.186.203

Petrescu, R.V., R. Aversa, B. Akash, J. Corchado and F. Berto et al., 2017y. About helicopters. J. Aircraft Spacecraft Technol., 1: 204-223. DOI: 10.3844/jastsp.2017.204.223

Petrescu, R.V., R. Aversa, B. Akash, R. Bucinell and J. Corchado et al., 2017a. Yield at thermal engines internal combustion. Am. J. Eng. Applied Sci., 10: 243-251. DOI: 10.3844/ajeassp.2017.243.251

Petrescu, R.V., R. Aversa, B. Akash, R. Bucinell and J. Corchado et al., 2017d. Inverse kinematics at the anthropomorphic robots, by a trigonometric method. Am. J. Eng. Applied Sci., 10: 394-411. DOI: 10.3844/ajeassp.2017.394.411

Petrescu, R.V., R. Aversa, B. Akash, R. Bucinell and J. Corchado et al., 2017e. Forces at internal combustion engines. Am. J. Eng. Applied Sci., 10: 382-393. DOI: 10.3844/ajeassp.2017.382.393

Petrescu, R.V., R. Aversa, B. Akash, R. Bucinell and J. Corchado et al., 2017f. Gears-Part I. Am. J. Eng. Applied Sci., 10: 457-472. DOI: 10.3844/ajeassp.2017.457.472

Petrescu, R.V., R. Aversa, B. Akash, R. Bucinell and J. Corchado et al., 2017g. Gears-part II. Am. J. Eng. Applied Sci., 10: 473-483. DOI: 10.3844/ajeassp.2017.473.483

Petrescu, R.V., R. Aversa, B. Akash, R. Bucinell and J. Corchado et al., 2017h. Cam-gears forces, velocities, powers and efficiency. Am. J. Eng. Applied Sci., 10: 491-505.

DOI: 10.3844 /ajeassp.2017.491.505 
Petrescu, R.V., R. Aversa, B. Akash, R. Bucinell and J. Corchado et al., 2017i. Dynamics of mechanisms with cams illustrated in the classical distribution. Am. J. Eng. Applied Sci., 10: 551-567. DOI: 10.3844/ajeassp.2017.551.567

Petrescu, R.V., R. Aversa, B. Akash, R. Bucinell and J. Corchado et al., 2017j. Testing by non-destructive control. Am. J. Eng. Applied Sci., 10: 568-583. DOI: 10.3844/ajeassp.2017.568.583

Petrescu, R.V., R. Aversa, B. Akash, R. Bucinell and J. Corchado et al., $2017 \mathrm{~m}$. Modern propulsions for aerospace-a review. J. Aircraft Spacecraft Technol., 1: 1-8. DOI: $10.3844 /$ jastsp.2017.1.8

Petrescu, R.V., R. Aversa, B. Akash, R. Bucinell and J. Corchado et al., 2017n. Modern propulsions for aerospace-part II. J. Aircraft Spacecraft Technol., 1: 9-17. DOI: 10.3844/jastsp.2017.9.17

Petrescu, R.V., R. Aversa, B. Akash, R. Bucinell and J. Corchado et al., 2017o. History of aviation-a short review. J. Aircraft Spacecraft Technol., 1: 30-49. DOI: 10.3844 /jastsp.2017.30.49

Petrescu, R.V., R. Aversa, B. Akash, R. Bucinell and J. Corchado et al., 2017p. Lockheed martin-a short review. J. Aircraft Spacecraft Technol., 1: 50-68. DOI: 10.3844 jastsp.2017.50.68

Petrescu, R.V., R. Aversa, B. Akash, T.M. Abu-Lebdeh and A. Apicella et al., 2018d. Buses running on gas. Am. J. Eng. Applied Sci., 11: 186-201. DOI: 10.3844/ajeassp.2018.186.201

Petrescu, R.V., R. Aversa, B. Akash, T.M. Abu-Lebdeh and A. Apicella et al., 2018e. Some aspects of the structure of planar mechanisms. Am. J. Eng. Applied Sci., 11: 245-259.

DOI: 10.3844/ajeassp.2018.245.259

Petrescu, R.V., R. Aversa, S. Kozaitis, A. Apicella and F.I.T. Petrescu, 2017l. The quality of transport and environmental protection, part I. Am. J. Eng. Applied Sci., 10: 738-755. DOI: 10.3844/ajeassp.2017.738.755

Petrescu, RV., R. Aversa, T.M. Abu-Lebdeh, A. Apicella and F.I.T. Petrescu, 2018f. The forces of a simple carrier manipulator. Am. J. Eng. Applied Sci., 11: 260-272. DOI: 10.3844/ajeassp.2018.260.272

Petrescu, RV., R. Aversa, T.M. Abu-Lebdeh, A. Apicella and F.I.T. Petrescu, 2018g. The dynamics of the otto engine. Am. J. Eng. Applied Sci., 11: 273-287. DOI: 10.3844/ajeassp.2018.273.287

Petrescu, RV., R. Aversa, T.M. Abu-Lebdeh, A. Apicella and F.I.T. Petrescu, 2018h. NASA satellites help us to quickly detect forest fires. Am. J. Eng. Applied Sci., 11: 288-296. DOI: 10.3844/ajeassp.2018.288.296

Petrescu, RV., R. Aversa, T.M. Abu-Lebdeh, A. Apicella and F.I.T. Petrescu, 2018i. Kinematics of a mechanism with a triad. Am. J. Eng. Applied Sci., 11: 297-308. DOI: 10.3844/ajeassp.2018.297.308
Pisello, A.L., G. Pignatta, C. Piselli, V.L. Castaldo and F. Cotana, 2016. Investigating the dynamic thermal behavior of building envelope in summer conditions by means of in-field continuous monitoring. Am. J. Eng. Applied Sci., 9: 505-519.

DOI: 10.3844/ajeassp.2016.505.519

Pourmahmoud, N., 2008. Rarefied gas flow modeling inside rotating circular cylinder. Am. J. Eng. Applied Sci., 1: 62-65. DOI: 10.3844/ajeassp.2008.62.65

Pravettoni, M., C.S.P. Lòpez and R.P. Kenny, 2016. Impact of the edges of a backside diffusive reflector on the external quantum efficiency of luminescent solar concentrators: Experimental and computational approach. Am. J. Eng. Applied Sci., 9: 53-63.

DOI: 10.3844 /ajeassp.2016.53.63

Qutbodin, K., 2010. Merging autopilot/flight control and navigation-flight management systems. Am. J. Eng. Applied Sci., 3: 629-630. DOI: 10.3844/ajeassp.2010.629.630

Rajbhandari, S., Z. Ghassemlooy and M. Angelova, 2011. The performance of a dual header pulse interval modulation in the presence of artificial light interferences in an indoor optical wireless communications channel with wavelet denoising. Am. J. Eng. Applied Sci., 4: 513-519. DOI: 10.3844/ajeassp.2011.513.519

Rajput, R.S., S. Pandey and S. Bhadauria, 2016. Correlation of biodiversity of algal genera with special reference to the waste water effluents from industries. Am. J. Eng. Applied Sci., 9: 1127-1133. DOI: 10.3844/ajeassp.2016.1127.1133

Rajupillai, K., S. Palaniammal and K. Bommuraju, 2015. Computational intelligence and application of frame theory in communication systems. Am. J. Eng. Applied Sci., 8: 633-637. DOI: 10.3844 /ajeassp.2015.633.637

Rama, G., D. Marinkovic and M. Zehn, 2016. Efficient co-rotational 3-node shell element. Am. J. Eng. Applied Sci., 9: 420-431. DOI: 10.3844 /ajeassp.2016.420.431

Raptis, K.G., G.A. Papadopoulos, T.N. Costopoulos and A.D. Tsolakis, 2011. Experimental study of load sharing in roller-bearing contact by caustics and photoelasticity. Am. J. Eng. Applied Sci., 4: 294-300. DOI: 10.3844/ajeassp.2011.294.300

Rea, P. and E. Ottaviano, 2016. Analysis and mechanical design solutions for sit-to-stand assisting devices. Am. J. Eng. Applied Sci., 9: 1134-1143. DOI: 10.3844/ajeassp.2016.1134.1143

Rhode-Barbarigos, L., V. Charpentier, S. Adriaenssens and O. Baverel, 2015. Dialectic form finding of structurally integrated adaptive structures. Am. J. Eng. Applied Sci., 8: 443-454.

DOI: 10.3844 /ajeassp.2015.443.454 
Riccio, A., R. Cristiano and S. Saputo, 2016b. A brief introduction to the bird strike numerical simulation. Am. J. Eng. Applied Sci., 9: 946-950. DOI: 10.3844 /ajeassp.2016.946.950

Riccio, A., U. Caruso, A. Raimondo and A. Sellitto, 2016a. Robustness of XFEM method for the simulation of cracks propagation in fracture mechanics problems. Am. J. Eng. Applied Sci., 9: 599-610. DOI: 10.3844/ajeassp.2016.599.610

Rich, F. and M.A. Badar, 2016. Statistical analysis of auto dilution vs manual dilution process in inductively coupled plasma spectrometer tests. Am. J. Eng. Applied Sci., 9: 611-624.

DOI: 10.3844/ajeassp.2016.611.624

Rohit, K. and S. Dixit, 2016. Mechanical properties of waste Biaxially Oriented Polypropylene Metallized Films (BOPP), LLDPE: LDPE Films with sisal fibres. Am. J. Eng. Applied Sci., 9: 913-920. DOI: 10.3844/ajeassp.2016.913.920

Rulkov, N.F., A.M. Hunt, P.N. Rulkov and A.G. Maksimov, 2016. Quantization of map-based neuronal model for embedded simulations of neurobiological networks in real-time. Am. J. Eng. Applied Sci., 9: 973-984. DOI: 10.3844/ajeassp.2016.973.984

Saikia, A. and N. Karak, 2016. Castor oil based epoxy/clay nanocomposite for advanced applications. Am. J. Eng. Applied Sci., 9: 31-40. DOI: 10.3844/ajeassp.2016.31.40

Sallami, A., N. Zanzouri and M. Ksouri, 2016. Robust diagnosis of a DC motor by bond graph approach. Am. J. Eng. Applied Sci., 9: 432-438.

DOI: 10.3844/ajeassp.2016.432.438

Samantaray, K.S., S. Sahoo and C.S. Rout, 2016. Hydrothermal synthesis of CuWO4-reduced graphene oxide hybrids and supercapacitor application. Am. J. Eng. Applied Sci., 9: 584-590. DOI: 10.3844/ajeassp.2016.584.590

Semin and R.A. Bakar, 2008. A technical review of compressed natural gas as an alternative fuel for internal combustion engines. Am. J. Eng. Applied Sci., 1: 302-311. DOI: 10.3844/ajeassp.2008.302.311

Semin S., A.R. Ismail and R.A. Bakar, 2009c. Diesel engine convert to port injection $\mathrm{CNG}$ engine using gaseous injector nozzle multi holes geometries improvement: A review. Am. J. Eng. Applied Sci., 2: 268-278. DOI: 10.3844/ajeassp.2009.268.278

Semin, A.R. Ismail and R.A. Bakar, 2009a. Combustion temperature effect of diesel engine convert to compressed natural gas engine. Am. J. Eng. Applied Sci., 2: 212-216. DOI: 10.3844/ajeassp.2009.212.216

Semin, A.R., Ismail and R.A. Bakar, 2009b. Effect of diesel engine converted to sequential port injection compressed natural gas engine on the cylinder pressure vs crank angle in variation engine speeds. Am. J. Eng. Applied Sci., 2: 154-159.

DOI: 10.3844 /ajeassp.2009.154.159
Sepúlveda, J.A.M., 2016. Outlook of municipal solid waste in bogota (Colombia). Am. J. Eng. Applied Sci., 9: 477-483. DOI: 10.3844/ajeassp.2016.477.483

Serebrennikov, A., D. Serebrennikov and Z. Hakimov, 2016. Polyethylene pipeline bending stresses at an installation. Am. J. Eng. Applied Sci., 9: 350-355. DOI: 10.3844/ajeassp.2016.350.355

Shanmugam, K., 2016. Flow dynamic behavior of fish oil/silver nitrate solution in mini-channel, effect of alkane addition on flow pattern and interfacial tension. Am. J. Eng. Applied Sci., 9: 236-250.

DOI: 10.3844/ajeassp.2016.236.250

Shruti, 2016. Comparison in cover media under stegnography: Digital media by hide and seek approach. Am. J. Eng. Applied Sci., 9: 297-302. DOI: 10.3844/ajeassp.2016.297.302

Stavridou, N., E. Efthymiou and C.C. Baniotopoulos, 2015a. welded connections of wind turbine towers under fatigue loading: Finite element analysis and comparative study. Am. J. Eng. Applied Sci., 8: 489-503. DOI: 10.3844/ajeassp.2015.489.503

Stavridou, N., E. Efthymiou and C.C. Baniotopoulos, $2015 \mathrm{~b}$. Verification of anchoring in foundations of wind turbine towers. Am. J. Eng. Applied Sci., 8: 717-729. DOI: 10.3844/ajeassp.2015.717.729

Suarez, L., T.M. Abu-Lebdeh, M. Picornell and S.A. Hamoush, 2016. Investigating the role of fly ash and silica fume in the cement hydration process. Am. J. Eng. Applied Sci., 9: 134-145.

DOI: 10.3844 /ajeassp.2016.134.145

Syahrullah, O.I. and N. Sinaga, 2016. Optimization and prediction of motorcycle injection system performance with feed-forward back-propagation method Artificial Neural Network (ANN). Am. J. Eng. Applied Sci., 9: 222-235.

DOI: 10.3844 /ajeassp.2016.222.235

Sylvester, O., I. Bibobra and O. Augustina, 2015b. Report on the evaluation of ugua J2 and J3 reservoir performance. Am. J. Eng. Applied Sci., 8: 678-688. DOI: 10.3844 /ajeassp.2015.678.688

Sylvester, O., I. Bibobra and O.N. Ogbon, 2015a. Well test and PTA for reservoir characterization of key properties. Am. J. Eng. Applied Sci., 8: 638-647. DOI: 10.3844/ajeassp.2015.638.647

Taher, S.A. R. Hematti and M. Nemati, 2008. Comparison of different control strategies in GAbased optimized UPFC controller in electric power systems. Am. J. Eng. Applied Sci., 1: 45-52. DOI: 10.3844 /ajeassp.2008.45.52

Takeuchi, T., Y. Kinouchi, R. Matsui and T. Ogawa, 2015. Optimal arrangement of energy-dissipating members for seismic retrofitting of truss structures. Am. J. Eng. Applied Sci., 8: 455-464. DOI: 10.3844/ajeassp.2015.455.464 
Theansuwan, W. and K. Triratanasirichai, 2011. The biodiesel production from roast thai sausage oil by transesterification reaction. Am. J. Eng. Applied Sci., 4: 130-132. DOI: 10.3844/ajeassp.2011.130.132

Thongwan, T., A. Kangrang and S. Homwuttiwong, 2011. An estimation of rainfall using fuzzy setgenetic algorithms model. Am. J. Eng. Applied Sci., 4: 77-81. DOI: 10.3844/ajeassp.2011.77.81

Tourab, W., A. Babouri and M. Nemamcha, 2011. Experimental study of electromagnetic environment in the vicinity of high voltage lines. Am. J. Eng. Applied Sci., 4: 209-213. DOI: 10.3844/ajeassp.2011.209.213

Tsolakis, A.D. and K.G. Raptis, 2011. Comparison of maximum gear-tooth operating bending stresses derived from niemann's analytical procedure and the finite element method. Am. J. Eng. Applied Sci., 4: 350-354. DOI: 10.3844/ajeassp.2011.350.354

Vernardos, S.M. and C.J. Gantes, 2015. Cross-section optimization of sandwich-type cylindrical wind turbine towers. Am. J. Eng. Applied Sci., 8: 471480. DOI: 10.3844/ajeassp.2015.471.480

Wang, J. and Y. Yagi, 2016. Fragment-based visual tracking with multiple representations. Am. J. Eng. Applied Sci., 9: 187-194. DOI: 10.3844/ajeassp.2016.187.194

Wang, L., G. Wang and CA. Alexander, 2015. Confluences among Big data, finite element analysis and high-performance computing. Am. J. Eng. Applied Sci., 8: 767-774. DOI: 10.3844/ajeassp.2015.767.774

Wang, L., T. Liu, Y. Zhang and X. Yuan, 2016. A methodology for continuous evaluation of cloud resiliency. Am. J. Eng. Applied Sci., 9: 264-273. DOI: 10.3844/ajeassp.2016.264.273

Waters, C., S. Ajinola and M. Salih, 2016. Dissolution sintering technique to create porous copper with sodium chloride using polyvinyl alcohol solution through powder metallurgy. Am. J. Eng. Applied Sci., 9: 155-165. DOI: 10.3844/ajeassp.2016.155.165

Wessels, L. and H. Raad, 2016. Recent advances in point of care diagnostic tools: A review. Am. J. Eng. Applied Sci., 9: 1088-1095.

DOI: 10.3844/ajeassp.2016.1088.1095

Yang, M.F. and Y. Lin, 2015. Process is unreliable and quantity discounts supply chain integration inventory model. Am. J. Eng. Applied Sci., 8: 602610. DOI: 10.3844 /ajeassp.2015.602.610

Yeargin, R., R. Ramey and C. Waters, 2016. Porosity analysis in porous brass using dual approaches. Am. J. Eng. Applied Sci., 9: 91-97.

DOI: 10.3844/ajeassp.2016.91.97

You, M., X. Huang, M. Lin, Q. Tong and X. Li et al., 2016. Preparation of LiCoMnO4 assisted by hydrothermal approach and its electrochemical performance. Am. J. Eng. Applied Sci., 9: 396-405. DOI: 10.3844/ajeassp.2016.396.405
Zeferino, R.S., J.A.R. Ramón, E. de Anda Reyes, R.S. González and U. Pal, 2016. Large scale synthesis of $\mathrm{ZnO}$ nanostructures of different morphologies through solvent-free mechanochemical synthesis and their application in photocatalytic dye degradation. Am. J. Eng. Applied Sci., 9: 41-52. DOI: 10.3844 /ajeassp.2016.41.52

Zhao, B., 2013. Identification of multi-cracks in the gate rotor shaft based on the wavelet finite element method. Am. J. Eng. Applied Sci., 6: 309-319. DOI: 10.3844/ajeassp.2013.309.319

Zheng, H. and S. Li, 2016. Fast and robust maximum power point tracking for solar photovoltaic systems. Am. J. Eng. Applied Sci., 9: 755-769. DOI: 10.3844 /ajeassp.2016.755.769

Zotos, I.S. and T.N. Costopoulos, 2009. On the use of rolling element bearings' models in precision maintenance, Am. J. Eng. Applied Sci., 2: 344-352. DOI: 10.3844/ajeassp.2009.344.352

Zulkifli, R., K Sopian, S Abdullah and MS Takriff, 2008. Effect of Pulsating Circular Hot Air Jet Frequencies on Local and Average Nusselt Number, Am. J. Eng. Applied Sci., 1: 57-61. DOI: 10.3844 /ajeassp.2008.57.61

Zulkifli, R., K. Sopian, S. Abdullah and M.S. Takriff, 2009. Experimental study of flow structures of circular pulsating air jet. Am. J. Eng. Applied Sci., 2: 171-175. DOI: 10.3844/ajeassp.2009.171.175

Zurfi, A. and J. Zhang, 2016a. Model identification and wall-plug efficiency measurement of white LED modules. Am. J. Eng. Applied Sci., 9: 412-419. DOI: 10.3844 /ajeassp.2016.412.419

Zurfi, A. and J. Zhang, 2016b. Exploitation of battery energy storage in load frequency control -a literature survey. Am. J. Eng. Applied Sci., 9: 1173-1188. DOI: 10.3844 /ajeassp.2016.1173.1188

\section{Source of Figures:}

https://www.google.com/search?q=the+International+Sp ace + Station\&client $=$ firefox-b-

$\mathrm{d} \&$ tbm $=$ isch\&source $=$ iu\&ictx $=1 \&$ fir $=\mathrm{g} 1$ RGJyEh4EoFG M\%253A\%252C3fVf0dyLCbxWEM\%252C\%252Fm\% 252F03wky\&vet $=1 \&$ usg $=$ AI4 -

kRQ0URt8beM2qqcV2e3SpIN8xnsqQ\&sa $=$ X\&ved $=2 \mathrm{ah}$ UKEwjPmPnIv8 hAhXJR5oKHbEICH0Q B0wEnoEC $\underline{\text { AwQBg\#\#imgrc }=8 \text { Hv7S-to5YwE1M:\&vet }=1}$ 